Florida International University FIU Digital Commons

$3-27-2015$

\title{
Changing Bacterial Growth Efficiencies across a Natural Nutrient Gradient in an Oligotrophic Estuary
}

Amber A. Kiger

Florida International University, aenns001@fiu.edu

DOI: $10.25148 /$ etd.FI15032176

Follow this and additional works at: https:// digitalcommons.fiu.edu/etd

Part of the Biogeochemistry Commons, and the Environmental Microbiology and Microbial Ecology Commons

\section{Recommended Citation}

Kiger, Amber A., "Changing Bacterial Growth Efficiencies across a Natural Nutrient Gradient in an Oligotrophic Estuary" (2015). FIU Electronic Theses and Dissertations. 1758.

https://digitalcommons.fiu.edu/etd/1758 


\title{
FLORIDA INTERNATIONAL UNIVERSITY \\ Miami, Florida
}

\section{CHANGING BACTERIAL GROWTH EFFICIENCES ACROSS A NATURAL NUTRIENT GRADIENT IN AN OLIGOTROPHIC ESTUARY}

\author{
A thesis submitted in partial fulfillment of the \\ requirements for the degree of \\ MASTER OF SCIENCE \\ in \\ GEOSCIENCES \\ by
}

Amber Alexis Kiger

2015 
To: Dean Michael Heithaus

College of Arts and Sciences

This thesis, written by Amber Alexis Kiger, and entitled Changing Bacterial Growth Efficiencies across a Natural Nutrient Gradient in an Oligotrophic Estuary, having been approved in respect to style and intellectual content, is referred to you for judgment.

We have read this thesis and recommend that it be approved.

Leonard J. Scinto

Joseph N. Boyer, Co-Major Professor

William Anderson, Co-Major Professor

Date of Defense: March 27, 2015

The thesis of Amber Alexis Kiger is approved.

\begin{tabular}{r} 
Dean Michael Heithaus \\
College of Arts and Sciences \\
\hline Dean Lakshmi N. Reddi \\
University Graduate School
\end{tabular}

Florida International University, 2015 


\section{DEDICATION}

This thesis is dedicated to my family for encouraging me to reach this point in my academic and scientific career. 


\section{ACKNOWLEDGMENTS}

I would like to thank the members of my committee for their support and guidance during the completion of this project. Dr. Leonard J. Scinto provided challenging questions and critiques that pushed my abilities as a scientist. Dr. Joseph Boyer was especially helpful during the early phases of this project, and I appreciate that he continued to be very involved in this work after leaving Florida International University. I particularly would like to thank my major professor, Dr. William Anderson for adopting me as a graduate student after Dr. Boyer left the university and dealing with my numerous questions and mini-crises.

I would also like to thank everyone who taught me various lab procedures and sampling methods, including Rafael Guevara, Sandro Stumpf, John Harris, Rachel Kotkowski, Amel Said, and George Berberian. Without the unique expertise of each of these individuals, this interdisciplinary project would have been less successful. I also wish to thank the Florida Coastal Everglades Long-Term Ecological Research program (DBI-0620409) for financial support of this research. 


\begin{abstract}
OF THE THESIS
CHANGING BACTERIAL GROWTH EFFICIENCIES ACROSS A NATURAL NUTRIENT GRADIENT IN AN OLIGOTROPHIC ESTUARY
\end{abstract}

by Amber Alexis Kiger

Florida International University, 2015

Miami, Florida

\title{
Professor William Anderson, Co-Major Professor \\ Professor Joseph N. Boyer, Co-Major Professor
}

Recent studies have characterized coastal estuarine systems as important components of the global carbon cycle. This study investigated carbon cycling through the microbial loop of Florida Bay by use of bacterial growth efficiency calculations. Bacterial production, bacterial respiration, and other environmental parameters were measured at three sites located along a historic phosphorus-limitation gradient in Florida Bay and compared to a relatively nutrient enriched site in Biscayne Bay. A new method for measuring bacterial respiration in oligotrophic waters involving tracing respiration of

${ }^{13} \mathrm{C}$-glucose was developed. The results of the study indicate that ${ }^{13} \mathrm{C}$ tracer assays may provide a better means of measuring bacterial respiration in low nutrient environments than traditional dissolved oxygen consumption-based methods on the basis of strong correlations between incubation length and $\delta^{13} \mathrm{C}$ values. Results also suggest that overall bacterial growth efficiency may be lower at the most nutrient limited sites. 


\section{TABLE OF CONTENTS}

\section{CHAPTER}

PAGE

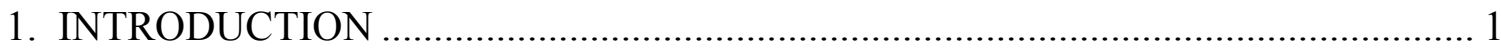

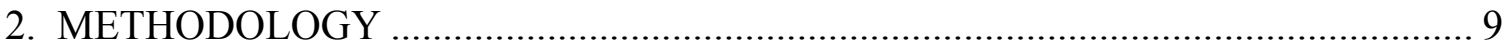

2.1 Study Site Description ............................................................................... 9

2.2 Sample Collection..................................................................................... 13

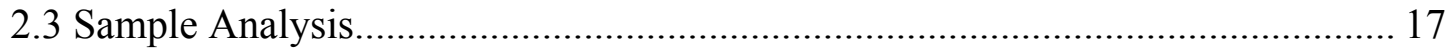

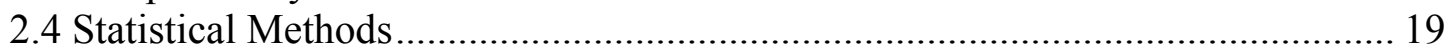

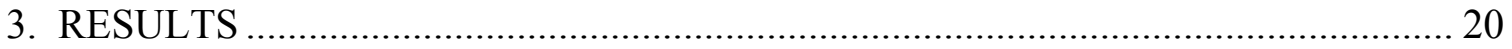

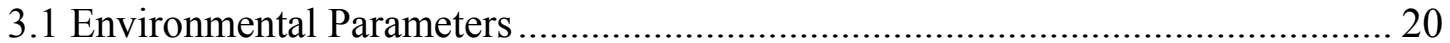

3.2 Bacterial Abundance and Bacterial Production ................................................... 21

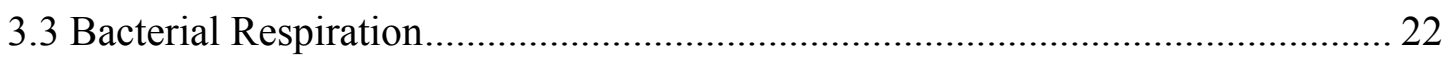

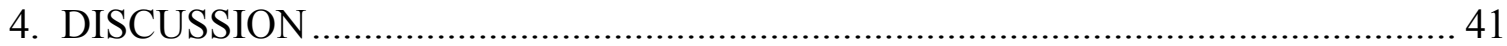

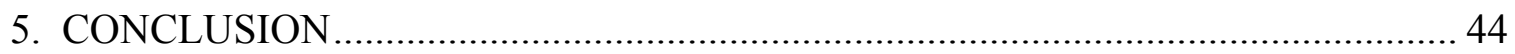




\section{LIST OF FIGURES}

FIGURE

PAGE

Figure 1: Diagram of the classical marine food chain and the microbial loop (modified from Robinson 2008).

Figure 2: Range of BGE reported in previous literature in rivers, oceans, lakes, and estuaries (modified from del Giorgio and Cole 1998).

Figure 3: Aerial image of Florida Bay and field collection sites (modified from Google Earth).

Figure 4: Aerial image of northern Biscayne Bay and the Oleta River Park sampling site (modified from Google Earth).

Figure 5: Process diagram showing sample collection scheme and sample treatments... 16

Figure 6: Average bacterial production values for each sampling event.

Figure 7: Carbon respired over time measured by Winkler titration for Sampling Event 1 .

Figure 8: Carbon respired over time measured by Winkler titration for samples collected on June 11 ${ }^{\text {th }}, 2013$ (Sampling Event 2).

Figure 9: Carbon respired over time measured by Winkler titration for samples collected on June $26^{\text {th }}, 2013$ (Sampling Event 3).

Figure 10: Carbon production determined by Winkler titration at TS-9, TS-10 and TS11 on July $24^{\text {th }}, 2013$ (Sampling Event 4).

Figure 11: $\delta^{13} \mathrm{C}$-DIC values at varying incubation times in samples labeled with ${ }^{13} \mathrm{C}$ glucose collected on May $23^{\text {rd }} 2013$.

Figure 12: $\delta^{13} \mathrm{C}$-DIC values at varying incubation times in unlabeled samples collected on May $23^{\text {rd }} 2013$.

Figure 13: $\delta^{13} \mathrm{C}$-DIC values at varying incubation times in labeled samples collected from Biscayne Bay on June $11^{\text {th }}, 2013$.

Figure 14: $\delta^{13} \mathrm{C}$-DIC values at varying incubation times in unlabeled samples collected from Biscayne Bay on June $11^{\text {th }}, 2013$. 30

Figure 15: $\delta^{13} \mathrm{C}$-DIC values at varying incubation times in labeled samples collected from Florida Bay site TS-9 on June 26 ${ }^{\text {th }}, 2013$. 
Figure 16: $\delta^{13} \mathrm{C}$-DIC values at varying incubation times in unlabeled samples collected

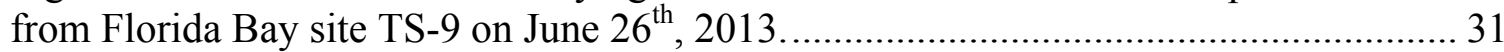

Figure 17: Changes in $\delta^{13} \mathrm{C}$-DIC in incubated ${ }^{13} \mathrm{C}$-labeled samples collected from TS9, TS- 10 , and TS- 11 on July $24^{\text {th }}, 2013$.

Figure 18: Changes in $\delta^{13} \mathrm{C}$-DIC in incubated unlabeled samples collected from TS-9, TS-10, and TS- 11 on July $24^{\text {th }}, 2013$.

Figure 19: Linear regression between mass 44 peak amplitude measured via GC-IRMS and DIC measured in parts per million for each sampling event. Graph A was generated for May $23^{\text {rd }}$ data, graph B for June $11^{\text {th }}$ data, graph C for June $26^{\text {th }}$ data and graph D for July $24^{\text {th }}$ data.

Figure 20: Relationship between $\delta^{13} \mathrm{C}$-DIC values converted into $\mu \mathrm{g} \mathrm{C} \mathrm{L}{ }^{-1}$ and incubation time for samples collected on May $23^{\text {rd }}, 2013$.

Figure 21: Relationship between $\delta^{13} \mathrm{C}$-DIC values converted into $\mu \mathrm{g} \mathrm{C} \mathrm{L}{ }^{-1}$ and incubation time for samples collected on June $26^{\text {th }}, 2013$.

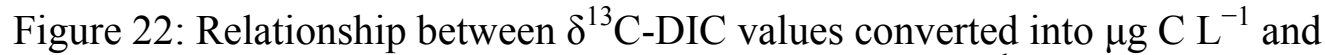
incubation time for unlabeled samples collected on July $24^{\text {th }}, 2013$. Graph A represents TS-9 data, graph B represents TS-10 data, and graph C represents TS-11 data.

Figure 23: Relationship between $\delta^{13} \mathrm{C}$-DIC values converted into $\mu \mathrm{g} \mathrm{C} \mathrm{L} \mathrm{L}^{-1}$ and incubation time for ${ }^{13} \mathrm{C}$-labeled samples collected on July $24^{\text {th }}, 2013$. Graph A represents TS-9 data, graph B represents TS-10 data, and graph C represents TS-11 data. 


\section{INTRODUCTION}

In light of increasing greenhouse gas concentrations and the threat of climate change, recent studies designed for quantifying potential carbon sinks have indicated that coastal marine systems are capable of storing carbon on a globally significant scale (Boullion et al. 2011, McLeod et al. 2011). A study by Donato et al. (2011) quantified carbon storage within mangrove systems, which are common along tropical and subtropical coastlines. The study indicated that mangrove systems on average store 1,023 megagrams carbon per hectacre $\left(\mathrm{Mg} \mathrm{Cha}^{-1}\right)$, storing significantly more carbon on average than upland tropical forests $\left(300 \mathrm{Mg} \mathrm{C} \mathrm{ha}^{-1}\right)$ that are typically considered in carbon sequestration efforts. Another study by Fourqurean et al. (2012a) quantified carbon storage within seagrass beds. The study concluded that seagrass meadows globally can store up to $829 \mathrm{Mg} \mathrm{C}$ ha $^{-1}$. As research continues in this field, more detailed quantification of coastal carbon budgets will be necessary in order to better understand the role of coastal communities in the global carbon cycle.

Current research is characterizing carbon budgets across different habitats and communities within the Everglades and Florida Bay. Fourqurean et al. (2012b) examined carbon storage under seagrass beds in Florida Bay, and showed that on average, Florida Bay seagrass beds store $163.5 \mathrm{Mg} \mathrm{C} \mathrm{ha}^{-1}$. The highest percentage of organic carbon (8\%) was found in sediment adjacent to the shoreline in Central Florida Bay. Smoak et al. (2013) measured carbon storage at two mangrove sites in the southwestern Everglades located on the Shark River and Harney River. The overall carbon burial rate, measured by ${ }^{210} \mathrm{~Pb}$ dating of sediment cores, was $151-168 \mathrm{~g} \mathrm{C} \mathrm{m}^{-2} \mathrm{yr}^{-1}$. A study by Engel et al. (2011), however, suggests that most carbon uptake in these mangrove forests is exported 
through tides as dissolved inorganic or organic carbon and does not accumulate in sediment. Although these components of the coastal Everglades carbon budget have been determined, more research is needed, particularly for carbon cycling within the Florida Bay water column.

Previous work has characterized air-water $\mathrm{CO}_{2}$ exchange in different parts of Florida Bay. DuFore (2012) measured $\mathrm{CO}_{2}$ exchange through floating chambers at 24 sites throughout Florida Bay. At Eastern Florida Bay sampling stations, water was found to be oversaturated with $\mathrm{CO}_{2}$. DuFore (2012) hypothesized that this oversaturation was a consequence of freshwater input from Taylor Slough. In Central Florida Bay, water was generally undersaturated with $\mathrm{CO}_{2}$ and acted as an atmospheric $\mathrm{CO}_{2}$ sink. DuFore (2012) did not quantify microbial data in this study; thus, the role of microbes in the sink or source status of Florida Bay is still unknown.

Water column microbial communities can often be a significant component of coastal and estuarine carbon cycles (Azam et al. 1983). Bacteria, phytoplankton and zooplankton can move $\mathrm{C}$ and nutrients across air-land-water boundaries and transform $\mathrm{C}$ into different organic and inorganic forms (Arrigo 2005). One particularly important energy and nutrient pathway utilized by bacteria is the microbial loop, which is considered separate from the classical marine food chain (Azam et al. 1983). Within the microbial loop, water column bacteria take up dissolved organic carbon (DOC) produced by other tropic levels and either respire the carbon as $\mathrm{CO}_{2}$ or convert it into bacterial biomass that moves back into the traditional food chain (Figure 1). 


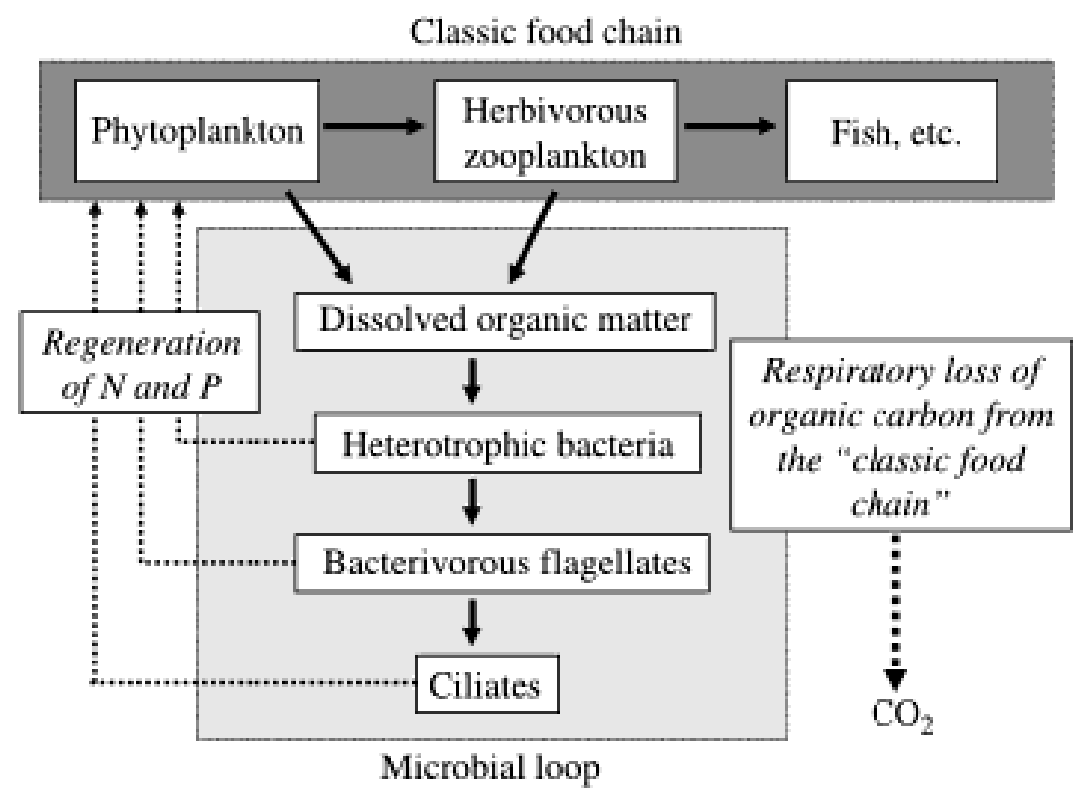

Figure 1: Diagram of the classical marine food chain and the microbial loop (modified from Robinson 2008).

Microbial loop carbon cycling processes can be quantified through bacterial growth efficiency measurements. Bacterial growth efficiency (BGE) is a ratio that indicates the proportion of bacterial carbon uptake that is used to produce biomass relative to the amount of carbon respired (del Giorgio et al. 1997). Bacterial growth efficiency is represented by the equation $\mathrm{BGE}=\mathrm{BP} /(\mathrm{BP}+\mathrm{BR})$, in which $\mathrm{BP}$ is bacterial production and BR is bacterial respiration (del Giorgio and Cole 1998). Both BP and BR are reported in $\mu \mathrm{g} \mathrm{C} \mathrm{L}^{-1} \mathrm{hr}^{-1}$. Numerous factors influence BGE, which ultimately influences the sequestration of carbon into biomass or loss of carbon to respiration in an aquatic or marine system. According to a review of global BGE calculations by del Giorgio and Cole (1998), BGE varies in different aquatic environments and increases along productivity gradients (Figure 2). Low BGE is expected in oligotrophic environments as a result of the energy cost of maintaining active transport systems and 
basic metabolic machinery. Mesotrophic and eutrophic areas, however, do not need to allocate as much energy for utilization of nutrients, so BGE tends to be higher in these waters.

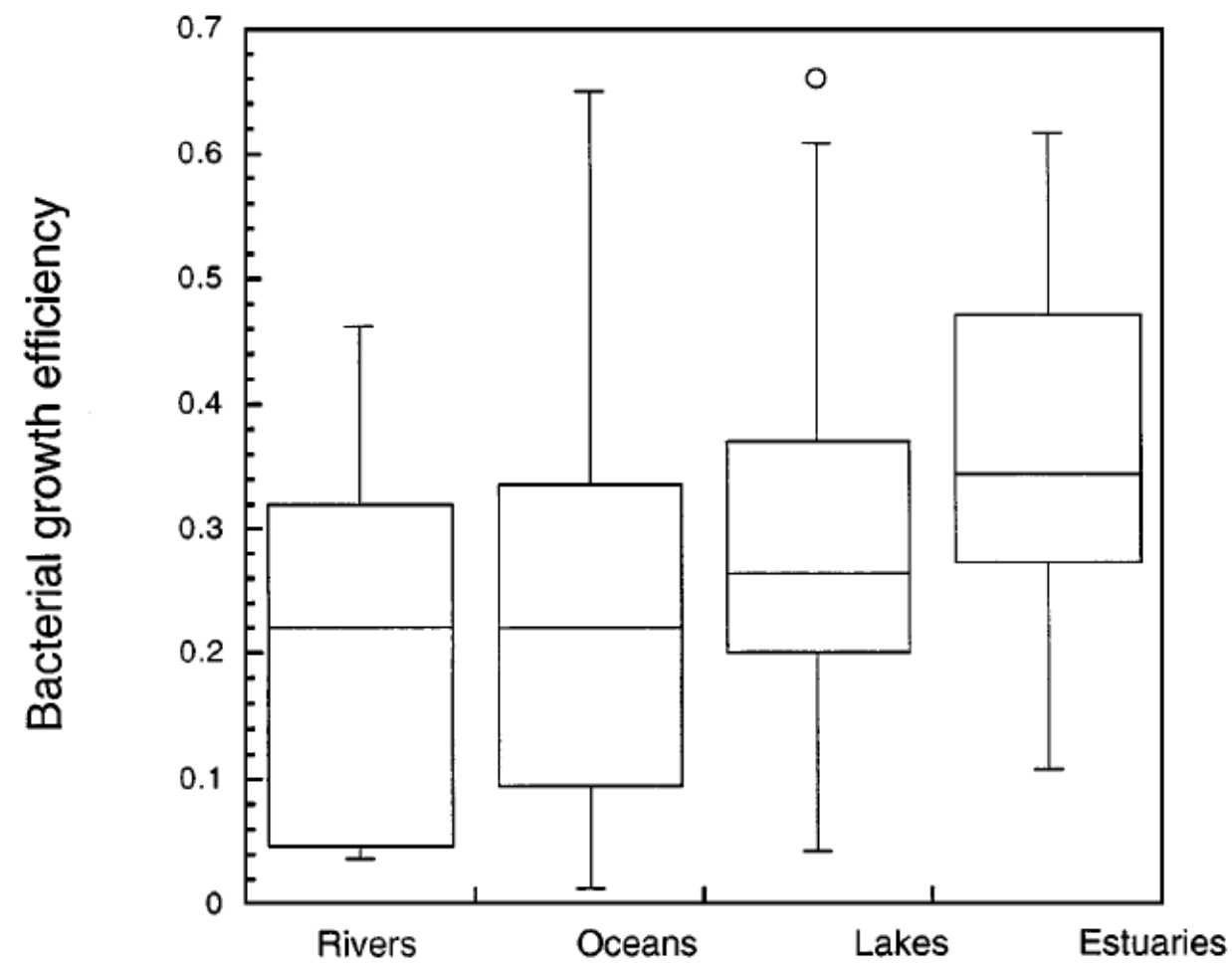

Figure 2: Range of BGE reported in previous literature in rivers, oceans, lakes, and estuaries (modified from del Giorgio and Cole 1998).

Although the del Giorgio and Cole (1998) study indicated that trophic state index was a main factor influencing BGE, other studies have investigated additional potential controls of BGE. Eiler et al. (2003) found that DOC concentration correlates with BGE in an asymptotic pattern, suggesting that DOC concentration affects BGE only in the most oligotrophic conditions. A study by Apple and del Giorgio (2007) showed that BGE positively correlated with long-term DOC lability in a temperate estuary, indicating that dissolved organic matter (DOM) source (quality) may impact BGE. A study 
conducted by Lennon and Pfaff (2005) showed that DOM with low C:P ratios (less than 160:1 by mol) from different sources was associated with high bacterial productivity, indicating that $\mathrm{P}$ availability can affect BGE values. A weak negative correlation between BGE and salinity was found in a study by Griffiths et al. (1984), but this correlation may have been an effect of productivity gradients rather than an effect of salinity gradients (del Giorgio and Cole 1998). Other potential controls on BGE, such as $\mathrm{N}$, are also examined in the del Giorgio and Cole (1998) review.

Methods to analyze BGE often involve measurement of BP via tritiated thymidine or leucine incorporation (Fuhrman and Azam 1982, Kirchman et al. 1985, Simon and Azam 1989) and measurement of $\mathrm{BR}$ through $\mathrm{O}_{2}$ consumption (Biddanda et al. 1994, Chin-Leo and Benner 1992). Samples collected for BR measurements are usually filtered to separate bacteria from larger organisms and then incubated in dark conditions to measure initial and final dissolved oxygen (DO) levels. Although the vast majority of BR measurements are made in this way (Robinson 2008), this method may not be ideal, especially for oligotrophic systems. Bacterial respiration measurements in oligotrophic waters often require long incubations ( 24 hours or greater) to obtain a detectable change in DO levels (del Giorgio and Cole 1998). A study by Aranguren-Gassis et al. (2012) concluded that DO consumption measurements lead to overestimation of BR rates in oligotrophic waters because of long incubation times altering the natural microbial community structure. In addition to long incubation times altering community structure, contamination of samples with atmospheric oxygen may impact results. Earth's atmosphere contains $21 \% \mathrm{O}_{2}$ while water contains DO at a concentration several orders of magnitude smaller (approximately 1-10 parts per million); thus, careful methodology 
must be used to avoid aeration of samples and atmospheric contamination (Friederich et al. 1991). Because DO consumption measurements may not be representative of natural BR in an oligotrophic environment, alternative methods should be developed to better assess BR and hence, BGE.

Carbon isotope tracer experiments may serve as an alternative method to determine BR. Early work on quantifying uptake and respiration of $\mathrm{C}$ focused on bacterial consumption of radiolabeled compounds, such as ${ }^{14} \mathrm{C}$-labeled glucose (Parsons and Strickland 1961, Hobbie and Crawford 1969). Although these studies were sensitive enough to measure respiration in low productivity systems (del Giorgio and Cole 1998), these measurements led to overestimates of BGE because of the simplicity of the compounds compared to natural food sources as well as isotopic dilution within the intracellular carbon pool (King and Berman 1984, Bjørnson 1986, Kirchman 2003). Measurement of natural stable isotope ratios before and after incubation rather than use of radioactive tracers may provide a way to measure BR in oligotrophic systems while overcoming concerns about use of simple tracer compounds. Natural stable isotope ratio measurement would involve bacterial consumption of a variety of simple and complex compounds, producing BR values more representative of field conditions. Ratios of ${ }^{12} \mathrm{C}$ and ${ }^{13} \mathrm{C}$ are utilized frequently in ecological studies (Fry 2006) and are usually reported as $\delta^{13} \mathrm{C}$ values (Craig 1957). Recent developments in isotope ratio mass spectrometry have created more precise methods for measuring $\delta^{13} \mathrm{C}$ in dissolved inorganic carbon (DIC) (St. Jean 2003, Torres et al. 2005). Tracking changes in $\delta^{13} \mathrm{C}$-DIC before and after dark incubation may serve as an alternative to both DO consumption methods and radioisotope methods for measuring $\mathrm{BR}$. 
Past studies have shown that DIC concentration, as well as $\delta^{13} \mathrm{C}$-DIC values, can be impacted by microbial activity (Torres et al. 2005); thus, known microbial impacts to $\delta^{13} \mathrm{C}$-DIC can be used to produce respiration measurements in the current study. Preferential uptake of ${ }^{12} \mathrm{C}$ by phytoplankton during photosynthesis can lead to $\delta^{13} \mathrm{C}$-DIC increases. Decay and bacterial processing of organic matter impacted by this biological fractionation, conversely, tends to decrease $\delta^{13} \mathrm{C}$-DIC values (Li and Liu 2011). Thus, size-filtered BR samples containing only natural sources of DOM (previously impacted by phytoplankton and higher trophic levels) would decrease in $\delta^{13} \mathrm{C}$-DIC over time. Samples with an isotopically labeled substrate, however, would have increasing $\delta^{13} \mathrm{C}$ DIC values over time as the labeled DIC is consumed and respired.

Studies that assess $\delta^{13} \mathrm{C}$-DIC values typically involve addition of a preservative to a water sample in order to prevent this microbial activity from occurring (Doctor et al. 2008, Li and Liu 2011). A study by Taipale and Sonninen (2009) specifically addressed the effects of collection vial type and preservation method on $\delta^{13} \mathrm{C}$-DIC values and found significant changes when samples were not properly stored or preserved. Other methods used to keep $\delta^{13} \mathrm{C}$-DIC values unchanged include filtration of samples, storage of samples under refrigeration, and complete filling of sample vials to prevent fractionation with air (Taipale and Sonninen 2009). In this study, the inhibition methods described above were used to stop biological activity at specific incubation intervals.

The primary objective of this study was to calculate baseline bacterial growth efficiency values at three historically oligotrophic sites (Childers et al. 2006) located in Florida Bay from bacterial production and bacterial respiration measurements. A secondary goal of this study was to develop an alternative method of measuring bacterial 
respiration using changes in $\delta^{13} \mathrm{C}$-DIC values. On the basis of previous research, BGE values were expected to positively correlate with historic trophic state index (TSI) and were expected to be lowest at the most oligotrophic site. In mesotrophic waters, traditional DO consumption methods were expected to be effective for measuring bacterial respiration and were expected to not differ significantly from the $\delta^{13} \mathrm{C}$-DIC method. In oligotrophic waters, however, the DO method was expected to be ineffective. Under these conditions, the $\delta^{13} \mathrm{C}$-DIC method was expected to detect respiration after less than 24 hours of incubation, while the DO method was expected to require incubations of 24 hours or longer to detect respiration. In summary, this study was expected to address the following three objectives and hypotheses:

Objective 1: To determine bacterial growth efficiencies across a natural nutrient gradient in Florida Bay.

H1: Bacterial growth efficiencies will positively correlate with historic trophic state index and nutrient stoichiometry.

Objective 2: To develop a method that detects BR in oligotrophic waters which is more sensitive and requires a shorter incubation time than traditional DO consumption-based measurements.

$\underline{\mathrm{H} 2}$ : In oligotrophic waters, $\delta^{13} \mathrm{C}$-DIC changes and DIC increases will be detectable after less than 24 hours of incubation. DO consumption, however, will not be detectable within 24 hours.

Objective 3: To determine whether measurements of $\delta^{13} \mathrm{C}$-DIC before and after dark incubation can serve as an alternative to traditional DO consumption measurements when determining bacterial respiration in a marine water sample. 
H3: Bacterial respiration values calculated by $\delta^{13} \mathrm{C}$-DIC measurements will not be significantly different than standard oxygen-based methods under mesotrophic or eutrophic conditions.

\section{METHODOLOGY}

\subsection{Study Site Description}

Florida Bay is a $1,600 \mathrm{~km}^{2}$ lagoonal estuary located between the southern tip of mainland Florida and the Florida Keys. Carbonate mud banks that restrict water circulation divide Florida Bay into shallow basins (Fourqurean and Robblee 1999). Taylor Slough, located north of the eastern side of the Bay, is the main terrestrial surface water source and provides over 90\% of the freshwater in Eastern Florida Bay (Swart and Price 2002). Conversely, Western Florida Bay lacks direct terrestrial surface water input resulting in rainfall being the primary freshwater input. Seasons are primarily defined by wet-dry precipitation cycles rather than air temperature. Approximately $60 \%$ of rainfall occurs from June-September, while $25 \%$ of rainfall occurs between November-April (Obeysekera et al. 1999). Florida Bay is characterized by occasional periods of hypersalinity, ranging up to $70 \mathrm{psu}$, when freshwater input from the Everglades is low (Boyer and Jones 2001, Robblee et al. 2001).

The geology of Florida Bay was briefly reviewed by Obeysekera et al. (1999). Oolitic Miami Limestone forms the bedrock foundation of Florida Bay. The Lower Florida Keys are composed of higher relief portions of oolitic Miami Limestone, while the Upper Florida Keys are composed of fossilized coral (Key Largo Limestone). The geologic foundations of the Florida Keys and Florida Bay were formed approximately 
100,000 years ago during the Sangamon interglacial (Hoffmeister 1974, Obeysekera et al. 1999). During this time, warm shallow seas covered the present-day Everglades and Florida Keys, creating conditions for both inorganic limestone formation (Miami Limestone- Oolitic) and biologic limestone formation (Key Largo Limestone, Miami Limestone- Bryozoan). The limestone foundation of Florida Bay is fairly flat; however, calcareous sediments have produced a network of banks and shallow basins throughout Florida Bay. The beginning of this sediment deposition began approximately 4000 years ago as sea level rise began to flood present-day Florida Bay. The bank and basin system is hypothesized to be a product of converging currents during flooding of Florida Bay, drowned marsh rills or minor bedrock depressions (Wanless and Tagett 1989, Obeysekera et al. 1999).

Physical, chemical, and nutrient limitation characteristics have been used to divide the bay into three biogeochemically distinct regions: Eastern Florida Bay, Central Florida Bay and Western Florida Bay (Boyer et al. 1997). Eastern Florida Bay, which is influenced by freshwater input from Taylor Slough, is strongly P-limited and is considered the most oligotrophic part of the Bay. Western Florida Bay is less P-limited and is more strongly influenced by oceanic connections with the Gulf of Mexico (Boyer et al. 1997). Central Florida Bay lies in the middle of this nutrient gradient and is characterized by high DOM, long water residence time, and periodic cyanobacterial blooms dominated by Synechococcus (Phlips et al. 1999, Boyer et al. 2006). This nutrient limitation pattern has led to Florida Bay being described as an "upside-down" estuary, meaning that limiting nutrients are derived from marine sources rather than terrestrial sources (Childers et. al 2006). 
Samples for this study were collected from three sites in Florida Bay that belong to the Florida Coastal Everglades Long-Term Ecological Research (FCE-LTER) network: TS-9, TS-10 and TS-11 (Figure 3). Each of these sites is representative of different biogeochemical conditions that exist in Florida Bay. TS-9 is a shallow estuarine site and is most representative of conditions in Eastern Florida Bay (Boyer et al. 2006). TS-10 and TS-11 are both representative of Central Florida Bay, but TS-11 experiences more exchange with the Gulf of Mexico and is located farther west along the nutrient gradient.

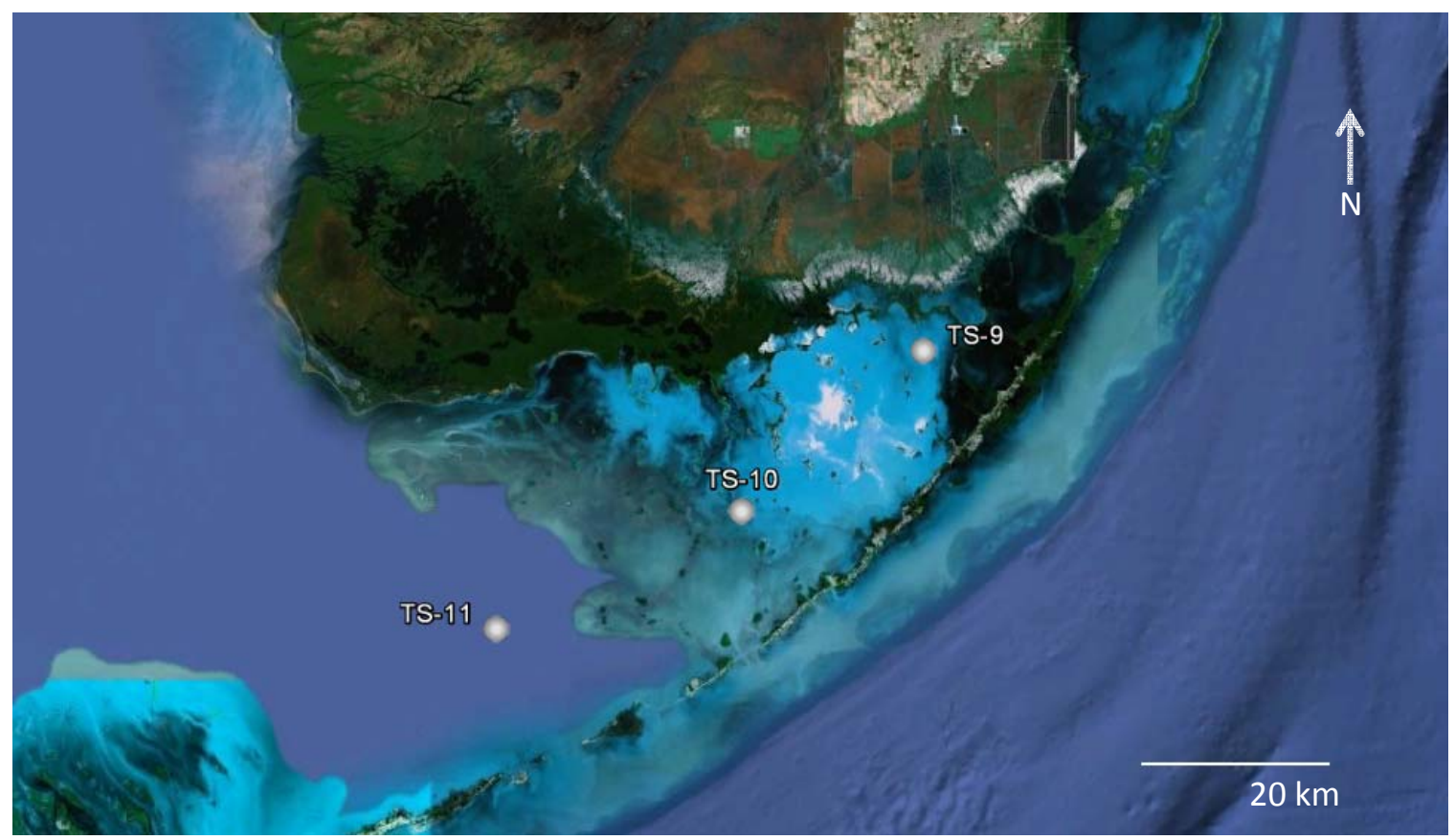

Figure 3: Aerial image of Florida Bay and field collection sites (modified from Google Earth).

In addition to the Florida Bay sites, a historically more nutrient enriched site in Biscayne Bay was selected for method development purposes (Figure 4). This site corresponds to site \#134 (Oleta River Park: $25.90500^{\circ} \mathrm{N}, 80.13333^{\circ} \mathrm{W}$ ) of the former SERC Water Quality Monitoring Network. This site, as well as others in northern 
Biscayne Bay, has been previously characterized as having elevated total $\mathrm{P}$ (up to 0.18 $\left.\mathrm{mg} \mathrm{L}^{-1}\right)$, high chlorophyll a $\left(0.96 \mu \mathrm{g} \mathrm{L}^{-1}\right)$, and low DO $(<4 \mathrm{ppm})$ in comparison to the rest of the Bay. These conditions have been attributed to nutrient input from canals, surrounding urban land use, and possible influence from the Munisport landfill (Caccia and Boyer 2005, Caccia and Boyer 2007). As a consequence of the mesotrophic nature of the site, changes in DO should be detectable over relatively short incubation times. Therefore, water samples collected from this site were expected to have matching bacterial respiration values whether measured by DO consumption or through ${ }^{13} \mathrm{C}$ respiration assays.

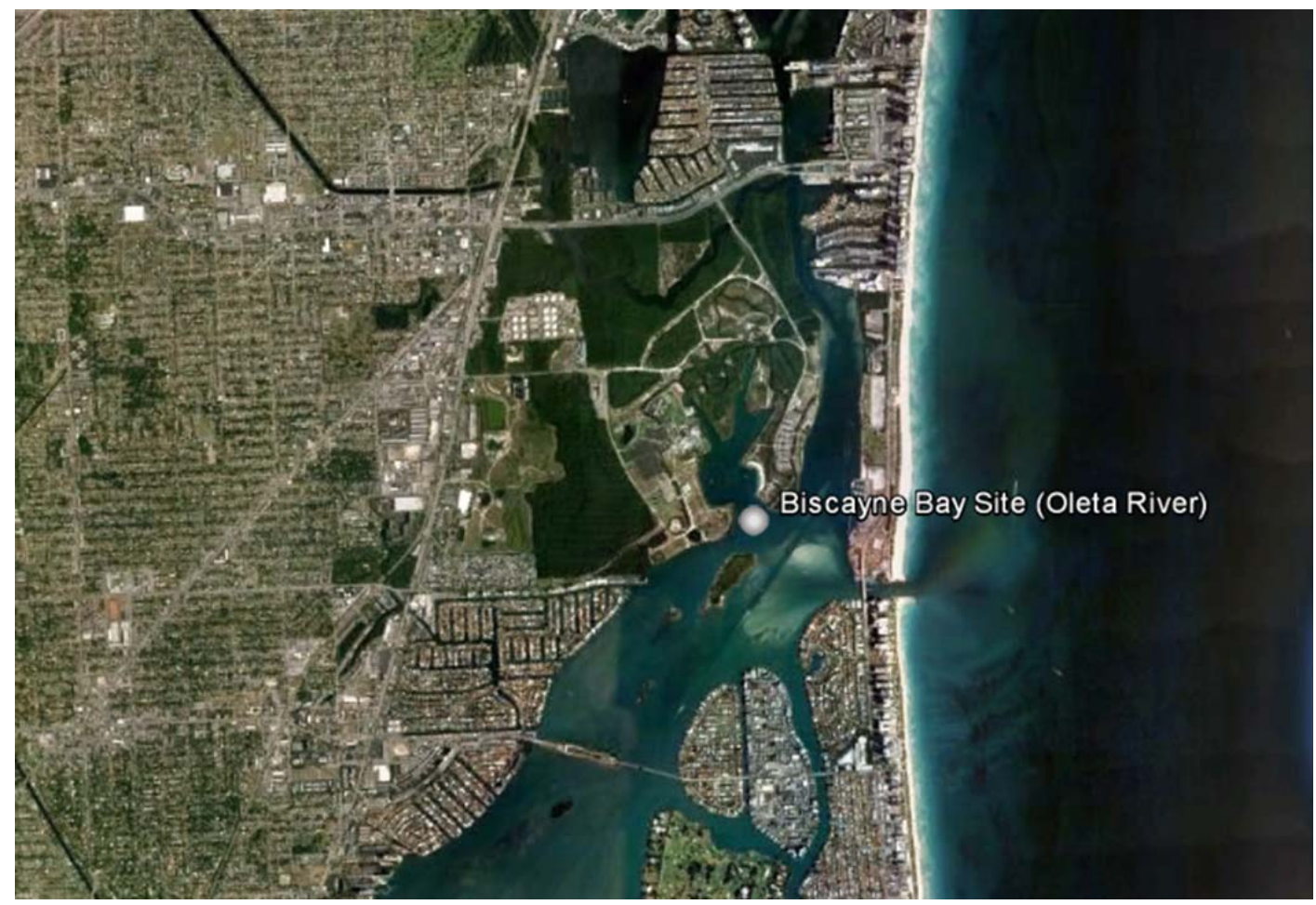

Figure 4: Aerial image of northern Biscayne Bay and the Oleta River Park sampling site (modified from Google Earth). 


\subsection{Sample Collection}

Initial samples for this study were collected on May 23, 2013 from the Biscayne Bay site starting at 9:50 AM. Thirty two samples for ${ }^{13} \mathrm{C}$-DIC analysis and twelve samples for DO analysis were collected. All samples collected during the initial sampling event were unfiltered, allowing the detection of maximum community respiration. Dissolved oxygen samples were collected first via peristaltic pump (E/S Environmental Sampler) from a depth of approximately $0.3 \mathrm{~m}$ into 1 liter amber narrowmouth HDPE bottles. Bottles were rinsed three times with sample water then gently filled from the bottom to prevent introduction of atmospheric $\mathrm{O}_{2}$ into the sample. Sample bottles were permitted to overflow by approximately one bottle volume before tubing was removed. The DO bottles were then sealed without headspace with parafilm (as a secondary gas barrier), capped (as a primary gas barrier), and placed into a box.

Three of the DO samples were collected directly into $125 \mathrm{ml}$ glass flasks for initial measurements $\left(t_{0}=0 \mathrm{~h}\right)$. Flasks were also filled from the bottom via silicone tubing until the flask overflowed. One $\mathrm{ml}$ of $3 \mathrm{M}$ manganous chloride solution and $1 \mathrm{ml}$ of $4 \mathrm{M}$ sodium iodate $/ 8 \mathrm{M}$ sodium hydroxide solution were then added to the flasks (Carpenter 1966, Friederich et al. 1991). The flasks were then capped with glass stoppers and inverted several times until a precipitate was distributed throughout each sample. At 8,12 , and $24 \mathrm{~h}$ after collection (initiation of dark incubations), water was transferred via peristaltic pump from the amber bottles into $125 \mathrm{ml}$ glass flasks. The procedure described for the initial samples $\left(\mathrm{t}_{0}=0 \mathrm{~h}\right)$ was repeated for the 8,12 and $24 \mathrm{~h}$ DO samples. 
Samples for ${ }^{13} \mathrm{C}$-DIC analysis were collected into $40 \mathrm{ml}$ amber glass vials. Silicone septa provided with the vials were replaced with butyl rubber septa to prevent atmospheric $\mathrm{CO}_{2}$ exchange (Taipale and Sonninen 2009). Fifteen of the vials contained 1 $\mathrm{ml}$ of ${ }^{13} \mathrm{C}$-glucose solution at a concentration of $6 \mu \mathrm{g} \mathrm{L}{ }^{-1}$. Sample vials were filled from the bottom via peristaltic pump and silicone tubing. These vials were filled until a positive meniscus formed to eliminate headspace. Sample vials containing ${ }^{13} \mathrm{C}$-glucose were not permitted to overflow in order to keep ${ }^{13} \mathrm{C}$-glucose concentrations similar in all vials. Six vials labeled as initial $(0 \mathrm{~h})$ vials were treated with one drop of saturated $\mathrm{HgCl}_{2}$ solution to stop biological activity and were then sealed with parafilm, capped and placed on ice in a cooler. All other vials were sealed with parafilm and capped without $\mathrm{HgCl}_{2}$ treatment. These samples were placed into a box and kept out of light to prevent photosynthetic processes. After 4, 8, 12 and $24 \mathrm{~h}$ of dark incubation at ambient temperatures $\left(25^{\circ} \mathrm{C}\right)$, six samples were treated with 1 drop of saturated $\mathrm{HgCl}_{2}$ solution, resealed and placed in a refrigerator at $4^{\circ} \mathrm{C}$. Remaining samples included a control that was not treated with $\mathrm{HgCl}_{2}$ and a control that contained approximately $2 \mathrm{~cm}$ of headspace to determine if the $\mathrm{HgCl}_{2}$ effectively stopped respiration and to determine if atmospheric air contamination impacted samples (Figure 5).

The second sampling event occurred on June 11, 2013 at a shoreline location adjacent to the Biscayne Bay site. Samples collected during this event were size filtered so that bacterial respiration rather than community respiration could be determined. This filtration was accomplished by placing an in-line filter holder ( $47 \mathrm{~mm}$ filter diameter, Millipore) containing $1 \mu \mathrm{m}$ pore filters (Whatman GF/B) between two sections of silicone tubing. This filtration pore size falls within the 3 to $0.6 \mu \mathrm{m}$ range used in other 
BGE studies to separate bacteria from larger organisms (Aranguren-Gassis 2012). All other sample treatments remained identical to the initial collection event. Incubation times were changed to 24,48 and 72 hours for both $\delta^{13} \mathrm{C}$-DIC and DO samples after a review of previous results.

The third sampling event occurred on June 26, 2013 at the TS-9 site in Florida Bay. Samples were size filtered as previously described. Incubation times were reduced to 12,24 and 48 hours after analysis of June $11^{\text {th }}$ results. The overall goal of the third sampling event was to determine the shortest incubation time that yielded significant results for oligotrophic Florida Bay samples. The fourth sampling event occurred on July $24^{\text {th }}, 2013$ and involved sample collection from all 3 Florida Bay sites. Initial samples and samples for 24 hour incubations were collected at each site.

During all sampling events, salinity and water temperature were measured for water density calculations and for use as general environmental parameters. An additional 1 liter water sample was collected during all sampling events for BP and bacterial abundance (BA) measurements. The bottles for $\mathrm{BP} / \mathrm{BA}$ analysis were rinsed three times, filled via peristaltic pump, and placed on ice in a cooler. 


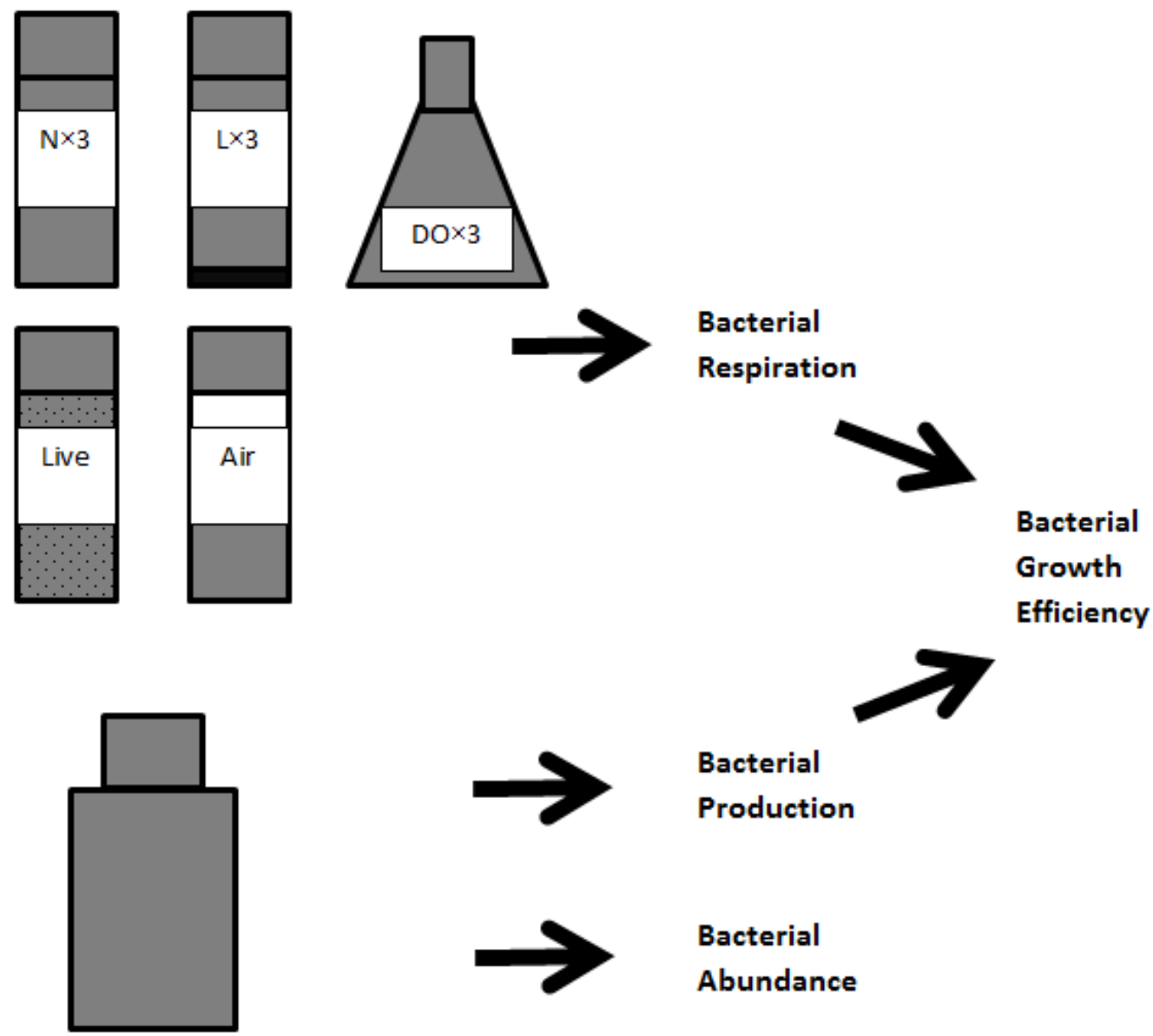

Figure 5: Process diagram showing sample collection scheme and sample treatments. 


\subsection{Sample Analysis}

The DO samples were analyzed using an automated Winkler titration system (modified from Friederich et al. 1991). Within one week of sample collection, flasks were opened and treated with $1 \mathrm{ml}$ of $5 \mathrm{M}$ sulfuric acid. Sodium thiosulfate solution $(0.14 \mathrm{~N})$ was then titrated into each sample, and the endpoint of each titration was detected via amperometric methods. Values were initially reported in $\mu \mathrm{mol} \mathrm{O} \mathrm{kg}^{-1} \mathrm{H}_{2} \mathrm{O}$ and were converted into $\mu \mathrm{g} C$ respired $\mathrm{L}^{-1}$ using water density calculations and a respiration quotient of 1 for conversion of $\mathrm{O}_{2}$ consumed to $\mathrm{CO}_{2}$ produced (del Giorgio and Cole 1998).

Samples collected for $\delta^{13} \mathrm{C}$-DIC measurements were analyzed using a Gas Bench II coupled to a Thermo Delta V GC-IRMS at the University of Miami Stable Isotope Laboratory (modified from Torres et al. 2005). Excess acid was added to each sample, allowing $\mathrm{CO}_{2}$ to accumulate in a headspace purged with helium above each sample. The accumulated $\mathrm{CO}_{2}$ was then processed by the GC-IRMS. $\delta^{13} \mathrm{C}$ values produced by the GC-IRMS were reported in reference to the Vienna Peedee Belemnite (VPDB) standard.

$\delta^{13} \mathrm{C}$-DIC values were further analyzed and converted into $\mu \mathrm{g} \mathrm{C}$ respired. First, $\delta^{13} \mathrm{C}$ values were converted into atom percent ${ }^{13} \mathrm{C}$ via the following equation:

$$
\text { atom } \%=100 \times \mathrm{AR} \times\left(\delta^{13} \mathrm{C} / 1000+1\right) / 1+\mathrm{AR} \times\left(\delta^{13} \mathrm{C} / 1000+1\right)
$$

in which AR is the absolute molar ratio of ${ }^{13} \mathrm{C}$ to ${ }^{12} \mathrm{C}(0.0111796)$. Next, peak amplitudes measured by GC-IRMS for ${ }^{12} \mathrm{CO}_{2}$ were converted into parts per million by plotting a linear regression between standards of known DIC concentration prepared for each sample run and measured peak amplitudes. The equation produced by the linear regression was then applied to convert peak amplitudes for each sample into ${ }^{12} \mathrm{C}$-DIC 
ppm. The resulting values were then multiplied by atom $\%{ }^{13} \mathrm{C}$ and ultimately converted

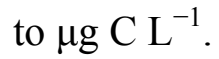

Both bacterial abundance (BA) and bacterial production (BP) were determined using methods described by Boyer et al. (2006). Bacterial abundance assays were performed using the DAPI staining technique (Coleman 1980, Porter and Feig 1980). Samples were fixed by treating $10 \mathrm{ml}$ of unfiltered water with $2 \mathrm{ml}$ of $20 \%$ formalin solution. After storage, samples were incubated for 20 minutes in dark conditions with DAPI stain at a final concentration of $25 \mu \mathrm{g} \mathrm{ml}^{-1}$. These samples were then filtered onto black $0.2 \mu \mathrm{m}$ polycarbonate filters and subsequently mounted onto slides. The slides were examined with an epifluorescence microscope illuminated with a $100 \mathrm{~W} \mathrm{Hg}$ bulb. The number of fluorescent bacteria within 10 different sampling fields of a known size per slide were counted. BA as cells $\mathrm{ml}^{-1}$ was then determined through use of the following formula:

$$
\mathrm{BA}=(\text { filtration area/field area }) * \mathrm{~N} / \mathrm{D}
$$

in which $\mathrm{N}$ is the total number of cells counted divided by the number of fields, and $\mathrm{D}$ is the volume of sample stained divided by the total volume of sample available.

Bacterial production was measured in unfiltered water samples via ${ }^{3} \mathrm{H}$-thymidine incorporation incubations (Bell 1993, Boyer et al. 2006). In summary, $10 \mathrm{ml}$ triplicates of each sample were placed into $50 \mathrm{ml}$ centrifuge tubes in addition to a $4 \%$ formalin blank sample. Samples were then treated with $100 \mu$ of ${ }^{3} \mathrm{H}$-thymidine solution and incubated for 1 hour. After incubation, samples were filtered, dried overnight, and treated with $10 \mathrm{ml}$ of scintillation cocktail. Samples were then placed into a liquid 
scintillation counter. Disintegrations per minute (dpm) were converted into moles thymidine $\mathrm{L}^{-1} \mathrm{hr}^{-1}$ using the following equation:

Moles thymidine $\mathrm{L}^{-1} \mathrm{hr}^{-1}=\left[\left(\mathrm{dpm}_{\text {sample }}-\mathrm{dpm}_{\text {blank }}\right)(\mathrm{C}) / \mathrm{SA} \times \mathrm{t} \times \mathrm{v}\right] \times 10^{-3} \times \mathrm{f}$ in which $\mathrm{C}$ is the number of curies per dpm, SA is the specific activity of the ${ }^{3} \mathrm{H}$ thymidine solution, $\mathrm{t}$ is the incubation time in hours, $\mathrm{v}$ is the filtered volume in liters, and $\mathrm{f}$ is a correction factor for addition of formaldehyde.

The result of the preceding equation was then converted into $\mu \mathrm{g} \mathrm{C} \mathrm{L}{ }^{-1} \mathrm{hr}^{-1}$ using the following formula:

$$
\mu \mathrm{g} \mathrm{C} \mathrm{L}^{-1} \mathrm{hr}^{-1}=\left(\text { moles thymidine } \mathrm{L}^{-1} \mathrm{hr}^{-1}\right) \times\left(2 \times 10^{18}\right) \times\left(1 \times 10^{-14}\right)
$$

in which $2 \times 10^{18}$ is the number of cells per mole thymidine and $1 \times 10^{-14}$ is the number of grams C per cell.

\subsection{Statistical Methods}

One way analysis of variance (ANOVA) was used to determine whether BR results were significantly different among incubation times for each sampling event, with significance set at $p<0.05$. Sets of incubation times that were found to be significantly different were then analyzed by Tukey's post hoc test to determine which pairs of incubation times were significantly different from each other. Welch's t-test was also used to compare pairs of incubation times with unequal variance among replicates. Incubation time averages, as well as BP results, were graphed with error bars representing a one sigma error unless otherwise noted. Tests of statistical significance were not used for salinity, water temperature, and BA. 


\section{RESULTS}

\subsection{Environmental Parameters}

As a result of the shallow estuarine nature of the study sites, salinity and water temperature varied between sampling events (Table 1). Salinity ranged from 17.0 to 34.7 practical salinity units, with the lowest salinity measured during the June $11^{\text {th }}$ Biscayne Bay sampling event and the highest measured at TS-10 on July $24^{\text {th }}$. Water temperature ranged from $27.3^{\circ} \mathrm{C}$ on May $23 \mathrm{rd}$ in Biscayne Bay to $30.7^{\circ} \mathrm{C}$ on July $24^{\text {th }}$ at TS-10. Light rainfall occurred during the June $11^{\text {th }}$ sampling event, while all other sampling occurred under dry, sunny conditions. Salinity on June $11^{\text {th }}$ was likely impacted by a tropical storm that left up to 13 inches of rain in localized parts of northern Miami-Dade County on June $7^{\text {th }}$ (Rainfall data from S29, South Florida Water Management District).

Table 1: Salinity and water temperature during each sampling event

\begin{tabular}{ccccc}
\hline $\begin{array}{c}\text { Sampling } \\
\text { Location }\end{array}$ & Sampling Date & $\begin{array}{c}\text { Sampling } \\
\text { Time }\end{array}$ & Salinity & $\begin{array}{c}\text { Water Temperature } \\
\left({ }^{\circ} \mathrm{C}\right)\end{array}$ \\
\hline Biscayne Bay-1 & May 23, 2013 & $9: 55$ AM & 27 & 27.3 \\
Biscayne Bay-2 & June 11, 2013 & $11: 50$ AM & 17 & 28.4 \\
TS-9 & June 26, 2013 & $10: 00$ AM & 33.4 & 28.9 \\
TS-9 & July 24, 2013 & $9: 25$ AM & 21.1 & 29.2 \\
TS-10 & July 24, 2013 & $10: 40$ AM & 34.7 & 30.7 \\
TS-11 & July 24, 2013 & $12: 05$ PM & 34.6 & 30.3 \\
\hline
\end{tabular}




\subsection{Bacterial Abundance and Bacterial Production}

BA ranged from 4.7 to $9.5 \times 10^{6}$ cells ml $^{-1}$ (Table 2). The highest counts were observed on June $11^{\text {th }}$ in Biscayne Bay, while the lowest valid counts were observed on July $24^{\text {th }}$ at TS-9. The May $23^{\text {rd }}$ counts fell below 300 cells per 10 visual fields (estimated total of $1.8 \times 10^{6}$ cells ml $^{-1}$ ); thus, these results are not valid (Boyer et al. 2006) and are not considered with the rest of the data set.

Table 2: Bacterial abundance at each sampling site

\begin{tabular}{ccc}
\hline Sampling Location & Sampling Date & Bacterial Abundance $\left(\right.$ cells ml $\left.{ }^{-1}\right)$ \\
\hline Biscayne Bay-1 & May 23, 2013 & $1.68 \mathrm{E}+06$ \\
Biscayne Bay-2 & June 11, 2013 & $9.49 \mathrm{E}+06$ \\
TS-9 & June 26, 2013 & $5.69 \mathrm{E}+06$ \\
TS-9 & July 24, 2013 & $4.72 \mathrm{E}+06$ \\
TS-10 & July 24, 2013 & $4.80 \mathrm{E}+06$ \\
TS-11 & July 24, 2013 & $4.94 \mathrm{E}+06$ \\
\hline
\end{tabular}

Bacterial production triplicate measurements for each sampling event were averaged without removing values that fell below the blank dpm measurement. Average BP measurements for Biscayne Bay on May $23^{\text {rd }}$ were below zero. This is a common result when BP is below method detection and does not truly denote negative production. The remaining BP averages ranged from 0.29 to $45.22 \mu \mathrm{g} \mathrm{C} \mathrm{L}^{-1} \mathrm{day}^{-1}$. The highest average was observed on June $11^{\text {th }}$ in Biscayne Bay and was an order of magnitude higher than all other averages. The two lowest averages, observed at TS-9 on June $26^{\text {th }}$ 
and TS-10 on July $24^{\text {th }}$, include triplicate values below the blank dpm measurement (Figure 6).

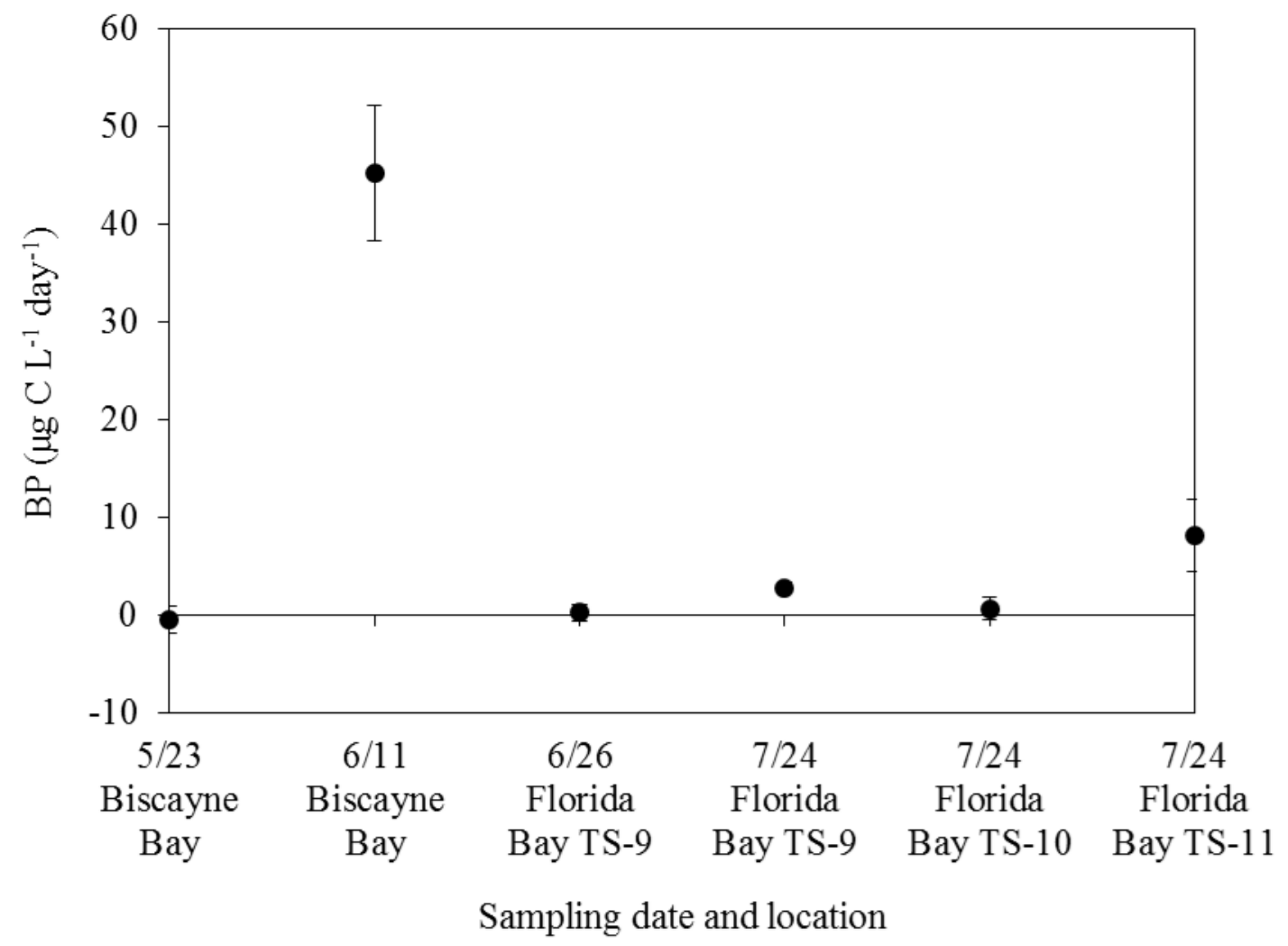

Figure 6: Average bacterial production values for each sampling event.

\subsection{Bacterial Respiration}

Dissolved oxygen levels measured by Winkler titrations were expected to decrease with increasing incubation time. During every sampling event, however, DO levels and corresponding $\mathrm{C}$ production calculations showed no statistically valid relationship with incubation length. DO levels measured for the first sampling event ranged from 185.6 to $199.5 \mu \mathrm{mol} \mathrm{O}_{2} \mathrm{~kg}^{-1} \mathrm{H}_{2} \mathrm{O}$. During the first sampling event, DO levels at each incubation length were found to not significantly differ from each other 
(ANOVA, $\mathrm{p}=0.39$ ). After DO values were converted to $\mathrm{C}$ respired over time, a significant correlation between incubation length and carbon increase was not found (Pearson $r=0.75, p=0.18$, Figure 7).

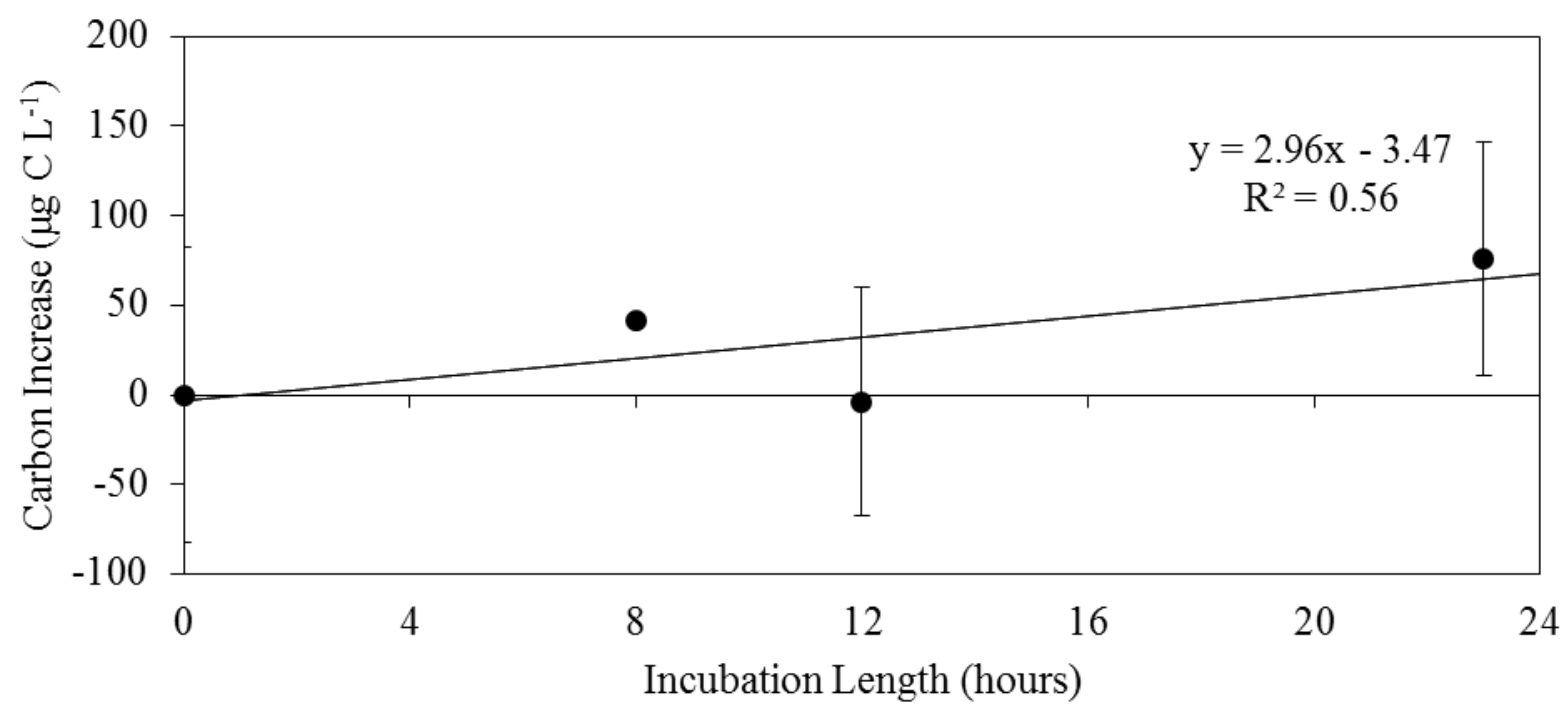

Figure 7: Carbon respired over time measured by Winkler titration for Sampling Event 1.

High replicate sample variability affected June $11^{\text {th }}$ DO results. DO levels measured for the June $11^{\text {th }}$ sampling event ranged from 171.5 to $193.7 \mu$ mol $\mathrm{O}_{2} \mathrm{~kg}^{-1} \mathrm{H}_{2} \mathrm{O}$. When converted to $\mathrm{C}$ respired over time, a significant negative correlation was found between incubation time and $\mathrm{C}$ concentration $(\mathrm{r}=-0.89, \mathrm{p}=0.049$, Figure 8$)$. Because this correlation was negative rather than positive, respiration of carbon cannot be determined from this data set. Although the correlation seems to indicate that DO concentrations increased during the incubation, DO values for each incubation time were found to not significantly differ from each other (ANOVA, $p=0.73$ ). 


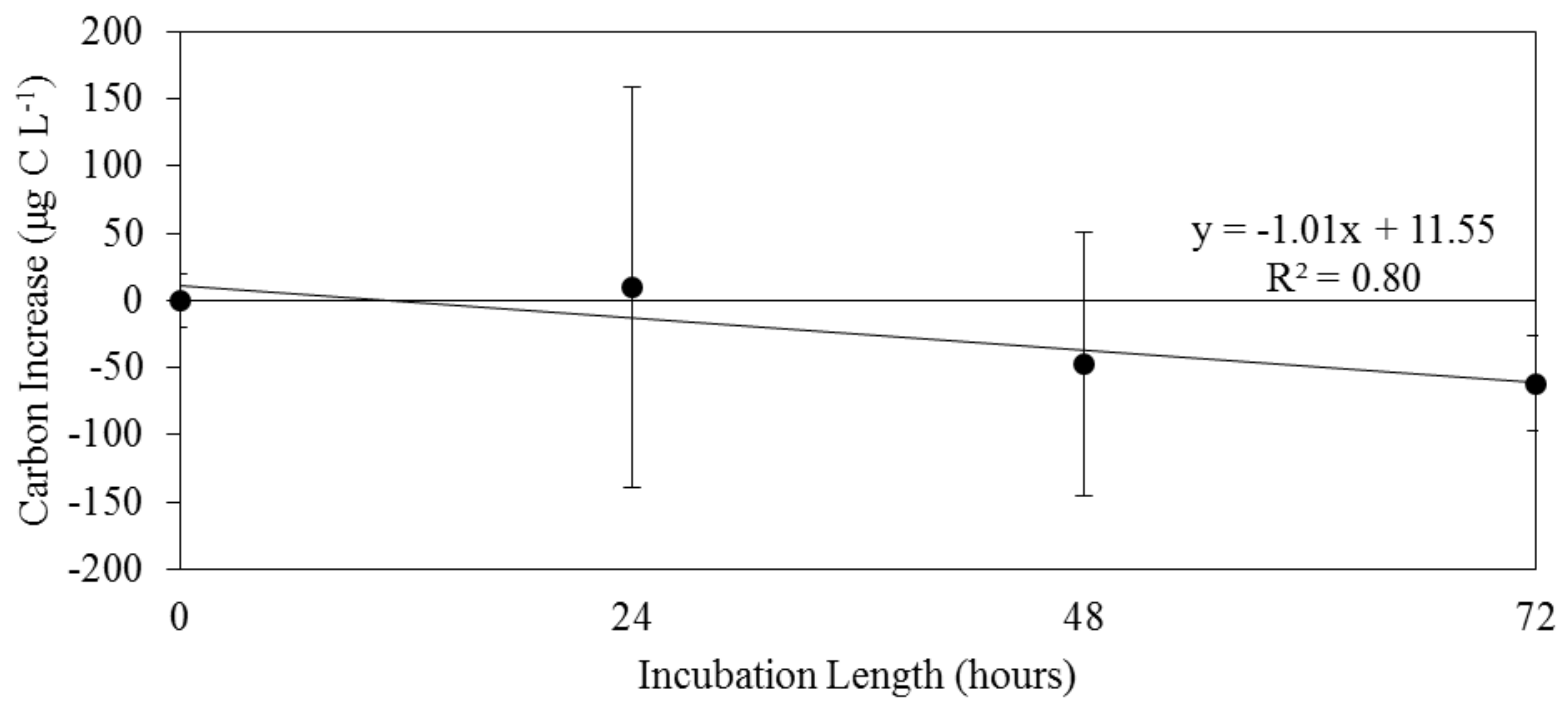

Figure 8: Carbon respired over time measured by Winkler titration for samples collected on June $11^{\text {th }}, 2013$ (Sampling Event 2).

Winkler titration results for June $26^{\text {th }}$ were also not reliable for determination of C respiration. Raw DO values ranged from 183.6 to $194.8 \mu \mathrm{mol} \mathrm{O} \mathrm{O}_{2} \mathrm{~kg}^{-1} \mathrm{H}_{2} \mathrm{O}$. Unlike Winkler titration data from May 23rd and June $11^{\text {th }}$, significant differences were found between incubation times (ANOVA, $\mathrm{p}=0.03$ ). Post-hoc analysis indicated that only the 12 hour and 48 hour $\mathrm{O}_{2}$ concentrations were significantly different. Similar to the June $11^{\text {th }}$ results, a negative correlation was found between carbon concentration and incubation time (Figure 9). This negative correlation, however, was statically insignificant $(r=-0.81, p=0.13)$, indicating replicate sample variability may have produced a false decreasing trend. 


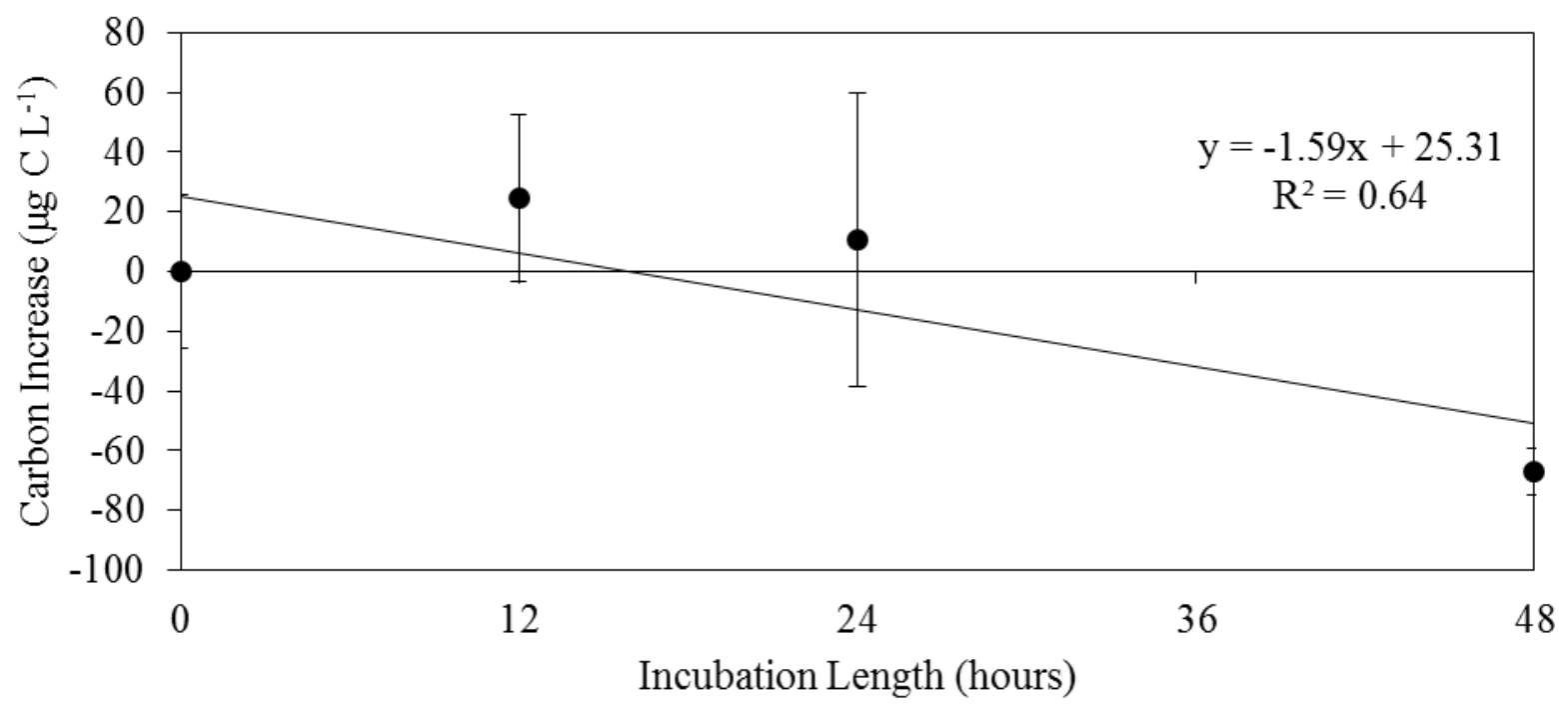

Figure 9: Carbon respired over time measured by Winkler titration for samples collected on June $26^{\text {th }}, 2013$ (Sampling Event 3).

Samples collected on July $24^{\text {th }}$ had an overall higher range of initial and final DO concentrations. The highest DO concentrations were observed at TS-10 (221.5 to 234.1 $\mu \mathrm{mol} \mathrm{kg}{ }^{-1}$ ), while the lowest overall concentrations were observed at TS-11 (187.2 to $211.9 \mu \mathrm{mol} \mathrm{O}_{2} \mathrm{~kg}^{-1}$ ). Initial DO concentrations at each site showed high variability. The average initial DO concentration at TS-9 was $217.3 \pm 5.8 \mu \mathrm{mol} \mathrm{O}_{2} \mathrm{~kg}^{-1}$ (reported with standard deviation), the average initial concentration at TS-10 was $229.9 \pm 7.3 \mu \mathrm{mol} \mathrm{O} 2$ $\mathrm{kg}^{-1}$, and the average initial concentration at TS-11 was $196.9 \pm 13.2 \mu \mathrm{mol} \mathrm{O}_{2} \mathrm{~kg}^{-1}$. A series of one-tailed Welch's t-tests performed on the DO concentrations at each site indicated that there were no significant differences between initial DO concentrations and final DO concentrations ( $\mathrm{p}=0.11,0.15,0.41$ for TS-9, TS-10 and TS-11, respectively). Although the difference between the initial and final DO values was not statistically significant, $\mathrm{BR}$ was still estimated for each site after conversion of $\mathrm{O}_{2}$ consumed to $\mathrm{C}$ 
produced (Figure 10). Results calculated from this conversion were $69.5 \mu \mathrm{g} \mathrm{C} \mathrm{L}^{-1} \mathrm{day}^{-1}$ for TS-9, $71.7 \mu \mathrm{g} \mathrm{C} \mathrm{L}^{-1}$ day $^{-1}$ for TS-10, and 23.5 $\mu \mathrm{g} \mathrm{C} \mathrm{L}^{-1}$ day $^{-1}$ for TS-11.

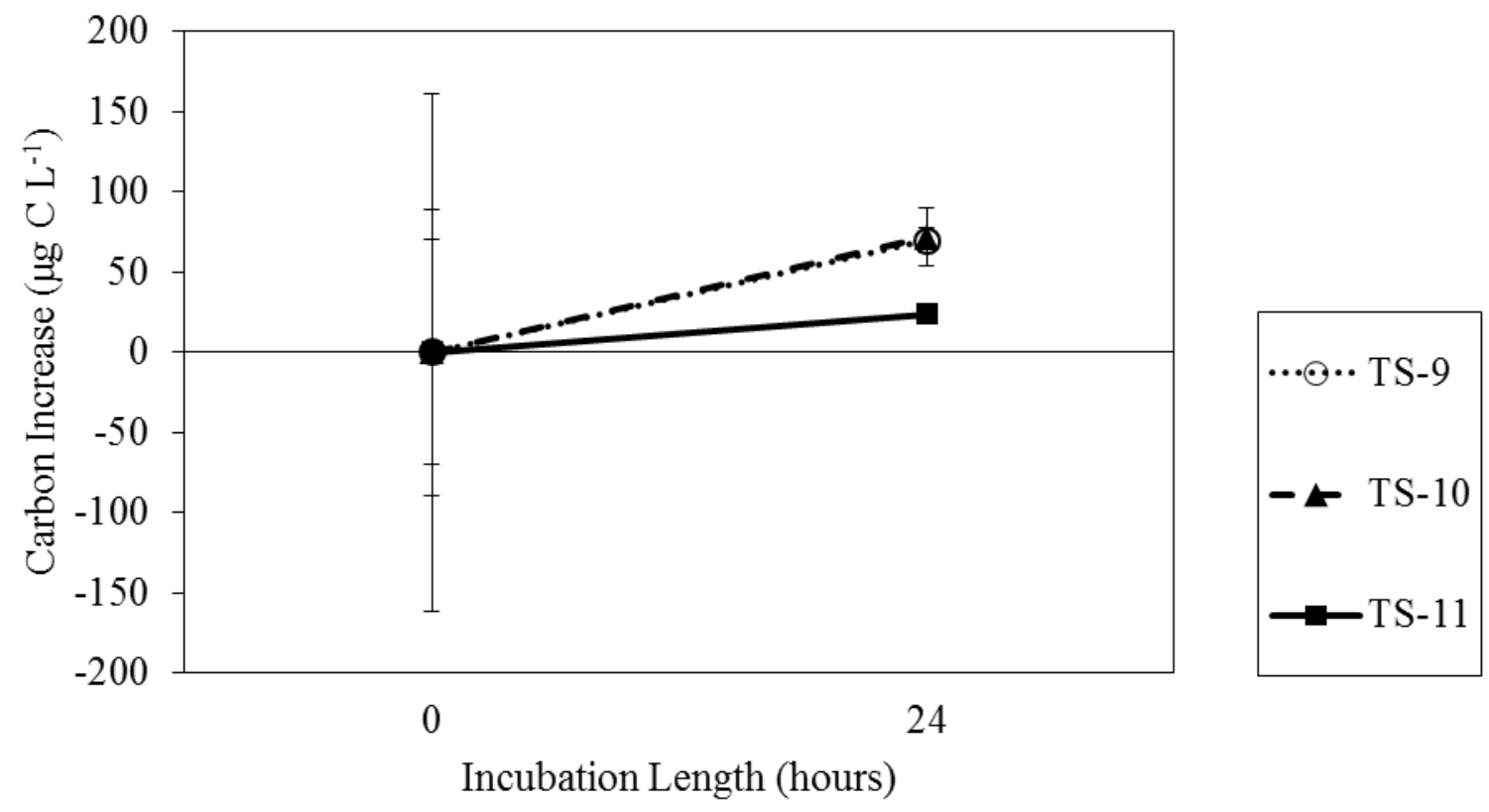

Figure 10: Carbon production determined by Winkler titration at TS-9, TS-10 and TS-11 on July $24^{\text {th }}, 2013$ (Sampling Event 4).

Use of ${ }^{13} \mathrm{C}$ isotope ratios to determine BR produced better results overall than the Winkler titration method. The labeled tracer method in comparison to the natural isotope ratio method produced stronger changes in $\delta^{13} \mathrm{C}$-DIC between incubation times. Clear BR results, however, were not observed for May $23^{\text {rd }}$ samples as a consequence of the very low ${ }^{13} \mathrm{C}$-glucose concentrations added to these samples $\left(1 \mathrm{ml}\right.$ of $6 \mu \mathrm{g} \mathrm{L}{ }^{-1}{ }^{13} \mathrm{C}$ glucose solution). $\delta^{13} \mathrm{C}$ values for samples collected on May $23^{\text {rd }}$ both before and after incubation ranged from $-3.67 \%$ to $-3.04 \%$. The sample $\delta^{13} \mathrm{C}$ range did not differ from either the air contamination control sample $\left(\delta^{13} \mathrm{C}=-3.32 \%\right)$ or the live control sample (sample not 
treated with $\mathrm{HgCl}_{2}, \delta^{13} \mathrm{C}=-3.24 \%$ ). Other than possible air contamination or ineffective $\mathrm{HgCl}_{2}$ treatment, these results indicated that incubation time was not sufficient to produce measurable respiration, or insufficient ${ }^{13} \mathrm{C}$-glucose was added to labeled samples. A twotailed t-test indicated that $\delta^{13} \mathrm{C}$ values in labeled samples were significantly higher than $\delta^{13} \mathrm{C}$ values in natural isotope samples $(\mathrm{p}=0.005)$. However, labeled samples showed a general decreasing trend in $\delta^{13} \mathrm{C}$ values rather than the expected increase over time (Figure 11). Additionally, $\delta^{13} \mathrm{C}$ values in natural isotope samples appeared to increase over time rather than decrease as expected (Figure 12). As a result of variability among replicate samples, incubation time did not show a significant relationship with $\delta^{13} \mathrm{C}$ values in either natural isotope samples or labeled samples $(\mathrm{p}=0.73,0.06$ for natural and labeled samples, respectively).

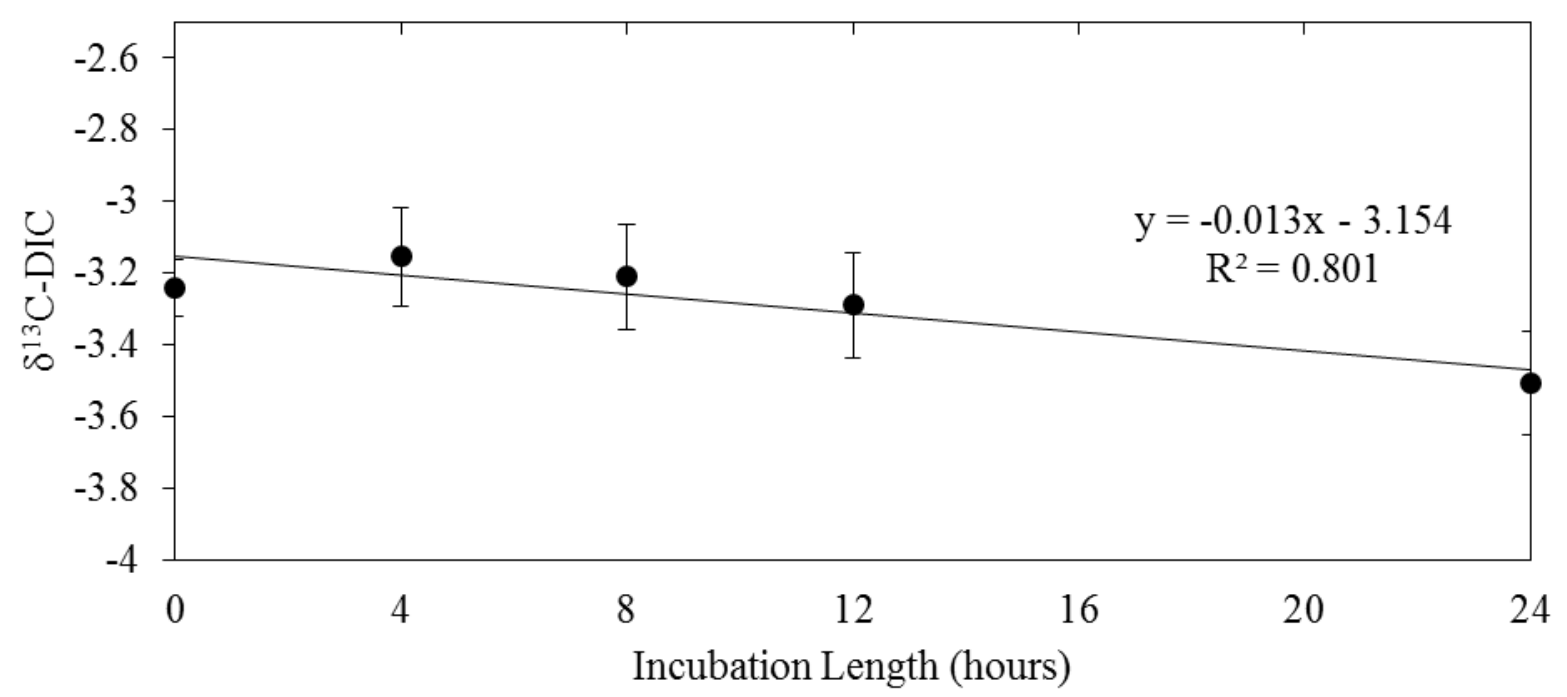

Figure 11: $\delta^{13} \mathrm{C}$-DIC values at varying incubation times in samples labeled with ${ }^{13} \mathrm{C}$ glucose collected on May $23^{\text {rd }} 2013$. 


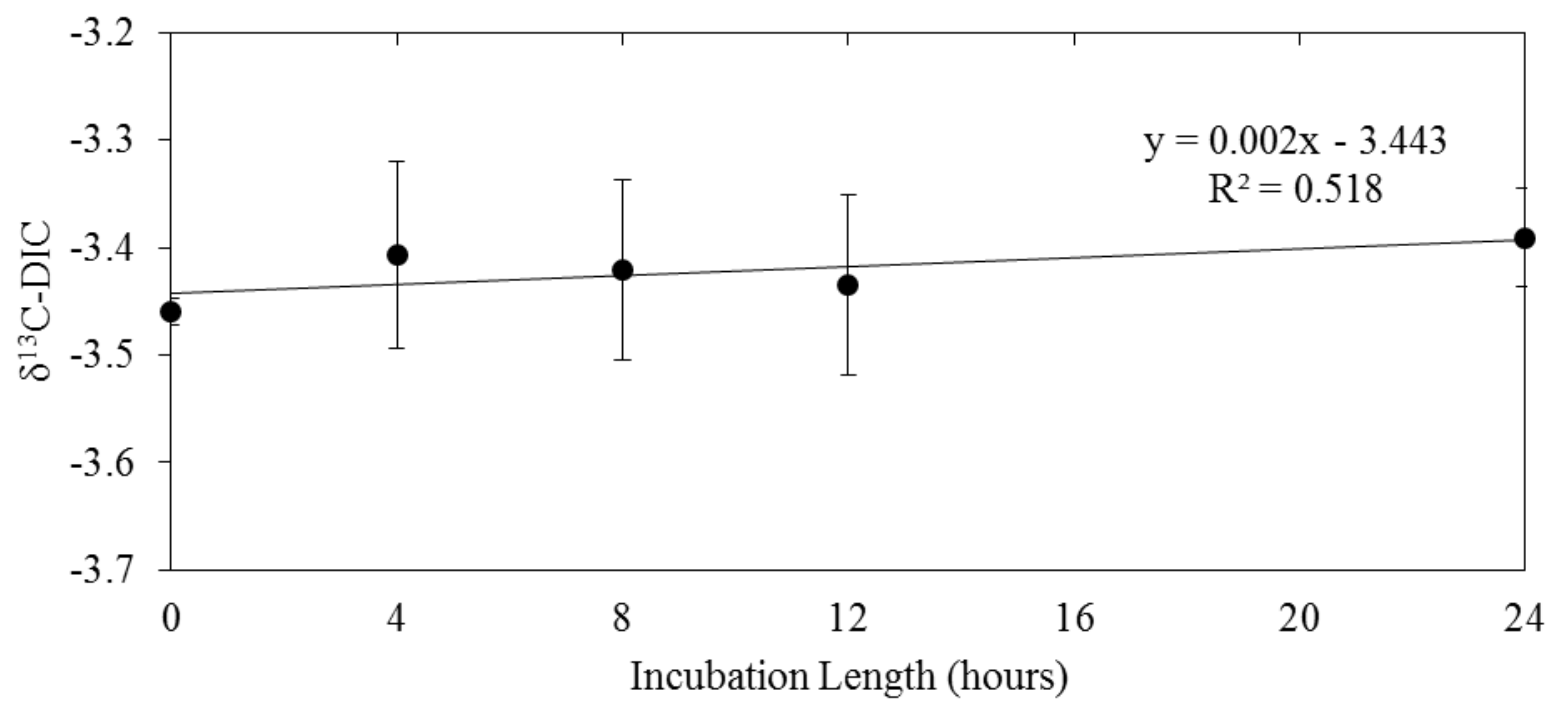

Figure 12: $\delta^{13} \mathrm{C}$-DIC values at varying incubation times in unlabeled samples collected on May $23^{\text {rd }} 2013$.

Although May $23^{\text {rd }}$ results showed a significant difference between labeled samples and unlabeled samples, more ${ }^{13} \mathrm{C}$-glucose was added to June $11^{\text {th }}$ labeled vials with the intention of increasing signal to noise ratios and to ensure ${ }^{13} \mathrm{C}$-glucose was being used as the primary bacterial food source. Concentration of ${ }^{13} \mathrm{C}$-glucose was increased to $0.6 \mathrm{mg} \mathrm{L}^{-1}$ in the stock ${ }^{13} \mathrm{C}$-glucose solution. $1 \mathrm{ml}$ of the stock solution was then added to each labeled vial before sample collection. Additionally, incubation times were increased from a maximum of 24 hours to a maximum of 72 hours.

$\delta^{13} \mathrm{C}$ values observed in samples collected on June $11^{\text {th }}$ showed stronger terrestrial influence, with initial $\delta^{13} \mathrm{C}$-DIC values ranging from $-8.28 \%$ to $-8.10 \%$ in both labeled and unlabeled samples. As a result of the increased concentration of ${ }^{13} \mathrm{C}$-glucose as a bacterial food source, a stronger correlation between incubation time and $\delta^{13} \mathrm{C}$ values was observed, and statistical differences were found among differing incubation times 
(ANOVA, $\mathrm{p}=2.40 \times 10^{-6}$ ). The most significant change in $\delta^{13} \mathrm{C}$-DIC was observed between the initial sample and the 24 hour labeled sample, with $\delta^{13} \mathrm{C}$-DIC values increasing from an average of $-8.15 \% \pm 0.08$ to $-4.32 \%$ \pm 0.13 (Figure $13, \mathrm{q}>\mathrm{q}_{\text {critical }}$ ). The air contaminated control sample and the non-preserved sample also differed from the 24 hour labeled sample (air control $\delta^{13} \mathrm{C}=-7.78 \%$, live control $\delta^{13} \mathrm{C}=-8.52 \%$ ). Beyond the 24 hour incubation point, $\delta^{13} \mathrm{C}$-DIC values did not significantly increase (Tukey’s HSD, $\mathrm{q}<\mathrm{q}_{\text {critical }}$ for $24 \mathrm{hr}$ vs. $48 \mathrm{hr}, 24 \mathrm{hr}$ vs. $72 \mathrm{hr}, 48 \mathrm{hr}$ vs. $72 \mathrm{hr}$ ), indicating that maximum biological uptake of ${ }^{13} \mathrm{C}$-glucose occurred at or before 24 hours (represented by dotted line in Figure 13). Unlabeled samples showed a general decrease in $\delta^{13} \mathrm{C}$-DIC over time (Figure 14). However, this decreasing trend in $\delta^{13} \mathrm{C}$-DIC was not statistically significant (ANOVA, $\mathrm{p}=0.09$ ).

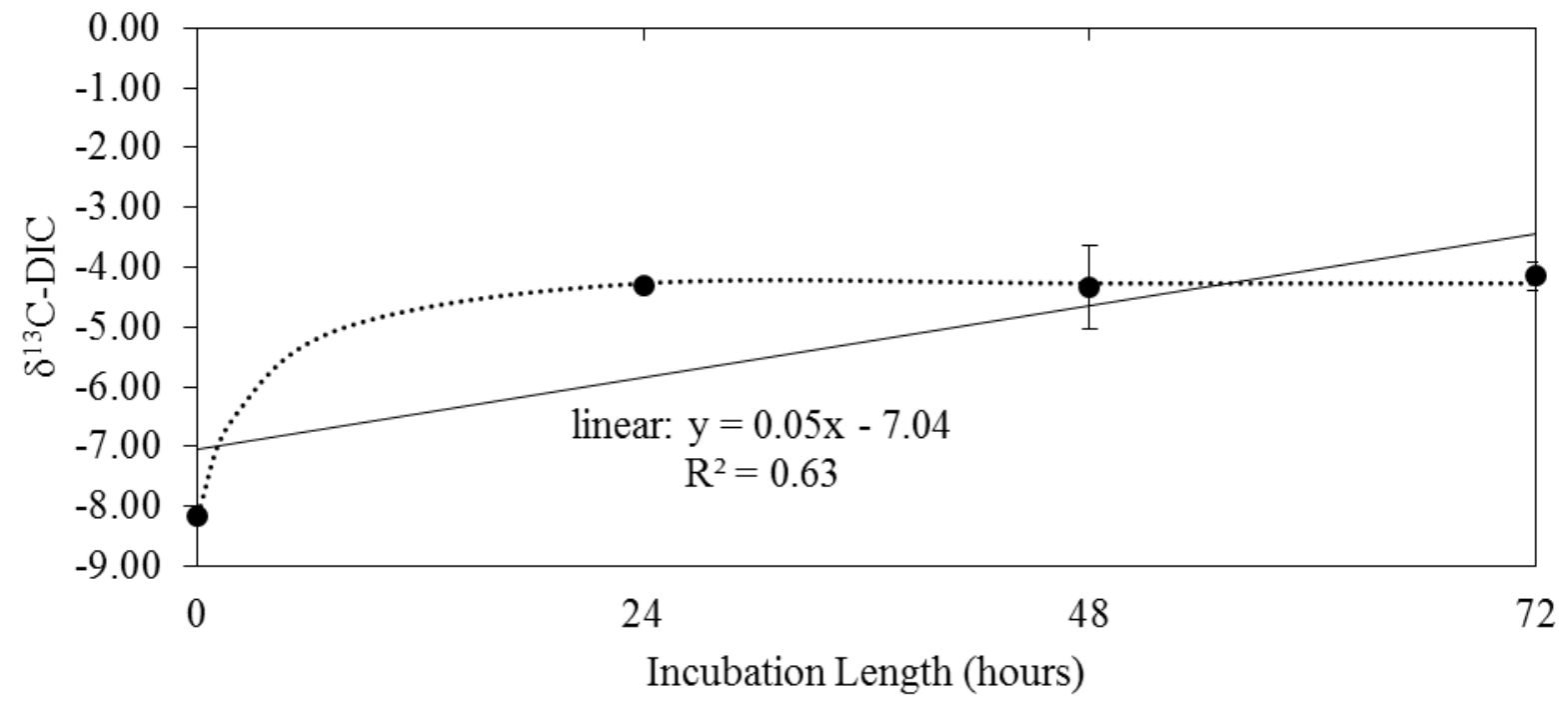

Figure 13: $\delta^{13} \mathrm{C}$-DIC values at varying incubation times in labeled samples collected from Biscayne Bay on June 11 ${ }^{\text {th }}, 2013$. 


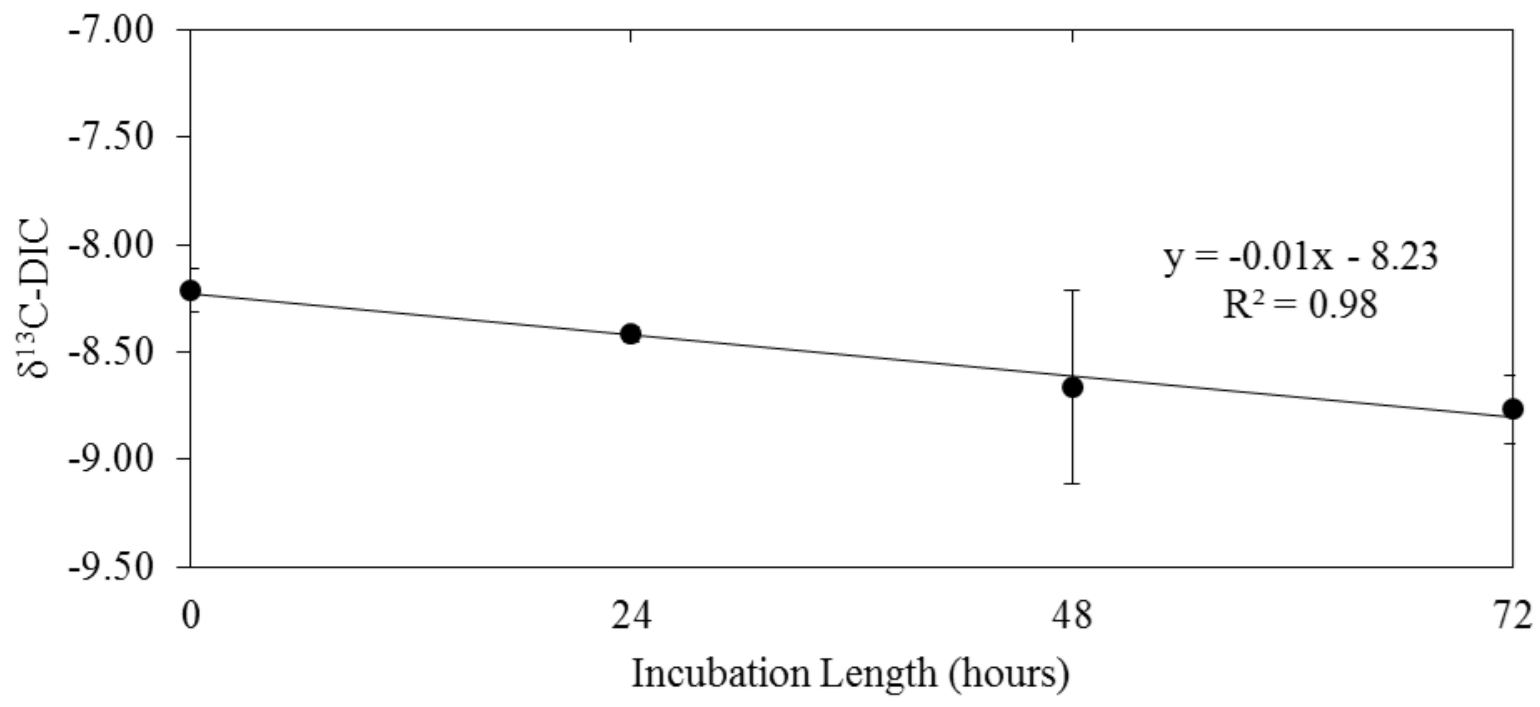

Figure 14: $\delta^{13} \mathrm{C}$-DIC values at varying incubation times in unlabeled samples collected from Biscayne Bay on June $11^{\text {th }}, 2013$.

After examination of June $11^{\text {th }}$ results, incubation times were shortened to a maximum of 48 hours on June $26^{\text {th }} . \delta^{13} \mathrm{C}$-DIC values in initial samples showed stronger marine influence than Biscayne Bay samples, with $\delta^{13} \mathrm{C}$-DIC values of $-2.28 \% \pm 0.18$ and $-2.30 \% \pm 0.27$ in unlabeled and labeled samples, respectively. Labeled samples showed a strong correlation between $\delta^{13} \mathrm{C}$-DIC values and incubation time (Figure 15). $\delta^{13} \mathrm{C}$-DIC values increased from $-2.30 \% \pm \pm 0.27$ to $7.46 \% \pm 0.88$ over the course of 48 hours. Significant differences were found among incubation times (ANOVA, $p<0.001$ ), and post-hoc analysis indicated $\delta^{13} \mathrm{C}$-DIC values for each incubation time significantly differed from all others. In unlabeled samples, a weak decrease in $\delta^{13} \mathrm{C}$-DIC values was observed (Figure 16). Although a high Pearson correlation coefficient was found $(\mathrm{r}=$ $-0.98)$, analysis of unlabeled sample results indicated that $\delta^{13} \mathrm{C}$-DIC values for each 
incubation time did not significantly differ from each other because of high replicate sample variability (ANOVA, $\mathrm{p}=0.55$ ).

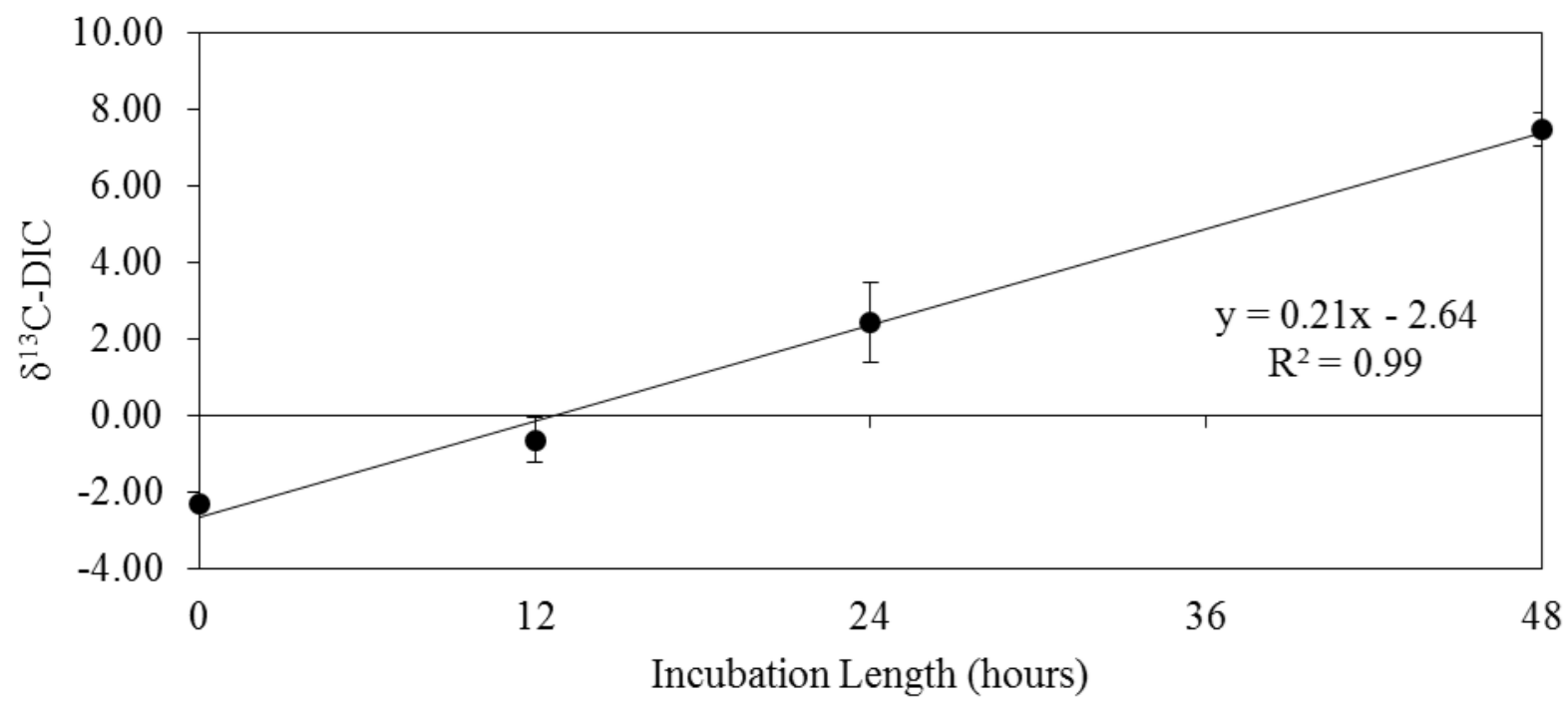

Figure 15: $\delta^{13} \mathrm{C}$-DIC values at varying incubation times in labeled samples collected from Florida Bay site TS-9 on June $26^{\text {th }}, 2013$.

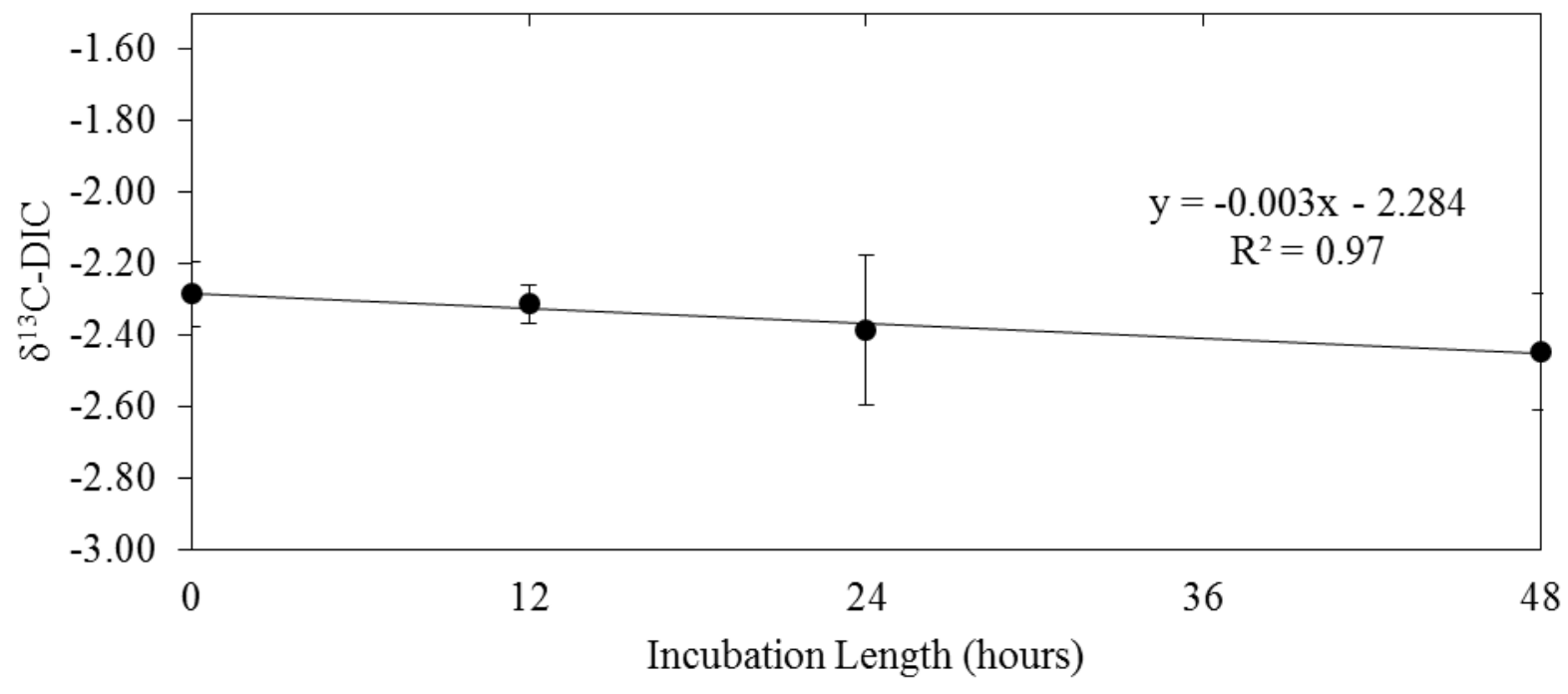

Figure 16: $\delta^{13} \mathrm{C}$-DIC values at varying incubation times in unlabeled samples collected from Florida Bay site TS-9 on June $26^{\text {th }}, 2013$. 
Initial $\delta^{13} \mathrm{C}$-DIC values from samples collected on July $24^{\text {th }}$ varied among sample sites. TS-9 had initial $\delta^{13} \mathrm{C}$-DIC values ranging from $-3.52 \%$ to $-3.33 \%$ in labeled and unlabeled samples. $\delta^{13} \mathrm{C}$-DIC initial values in TS-10 samples ranged from $-1.44 \%$ to $-1.13 \%$, and initial $\delta^{13} \mathrm{C}$-DIC values at TS-11 ranged from $-1.89 \%$ to $-1.42 \%$. Further analysis indicated that all 3 sample sites had significantly different initial $\delta^{13} \mathrm{C}$-DIC values from each other (ANOVA, $\mathrm{p}=8.89 \times 10^{-14}$; Tukey's HSD, $\mathrm{q}>\mathrm{q}_{\text {critical }}$ for all site combinations). In labeled samples incubated for 24 hours, $\delta^{13} \mathrm{C}$-DIC increased for TS-9 and TS-11, but not for TS-10 (Figure 17). TS-11 showed the largest change in $\delta^{13} \mathrm{C}-\mathrm{DIC}$, increasing from an average of $-1.56 \%$ to $+6.28 \%$ over the 24 hour incubation period. Samples from TS-9 had a smaller increase from an average of $-3.35 \%$ to $-0.90 \%$. Statistical analysis confirmed that the increases in $\delta^{13} \mathrm{C}$-DIC over time at TS-9 and TS-11 were significant (Welch's one-tailed t-test; TS-9, $p=0.03$; TS-11, $p=0.01$ ). Labeled samples from TS-10, however, showed an apparent decrease in $\delta^{13} \mathrm{C}$-DIC values over time. The initial samples from TS-10 had an average $\delta^{13} \mathrm{C}$-DIC value of $-1.39 \%$, while final samples had an average value of $-1.43 \%$. Further analysis indicated that this decrease was not significant $(\mathrm{p}=0.11)$. 


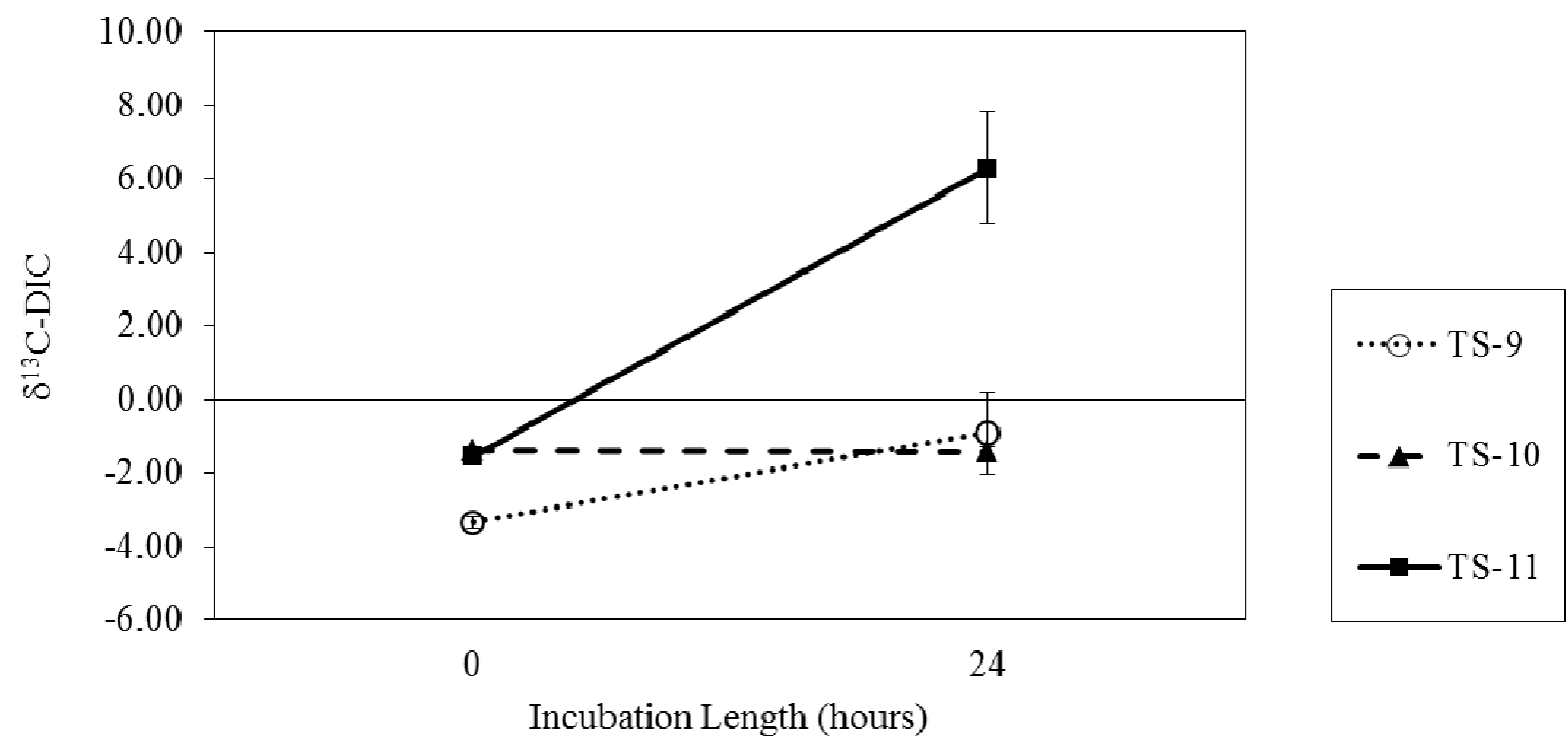

Figure 17: Changes in $\delta^{13} \mathrm{C}$-DIC in incubated ${ }^{13} \mathrm{C}$-labeled samples collected from TS-9, TS-10, and TS-11 on July $24^{\text {th }}, 2013$.

Similar to samples collected on other dates, unlabeled samples from July $24^{\text {th }}$ overall did not considerably change in $\delta^{13} \mathrm{C}$-DIC during the incubation period (Figure 18). In samples from $\mathrm{TS}-10, \delta^{13} \mathrm{C}$-DIC values decreased from $-1.30 \%$ to $-1.64 \%$. High sample variance caused this apparent decrease to be statistically invalid $(p=0.11)$. In samples from TS-11, $\delta^{13} \mathrm{C}$-DIC values increased from an average of $-1.60 \%$ to $-1.56 \%$ during the incubation; again, this change was not supported statistically $(p=0.36)$. TS-9 samples, however, did undergo a significant decrease from $-3.40 \%$ to $-3.55 \%$ o $(\mathrm{p}=$ $0.02)$. 


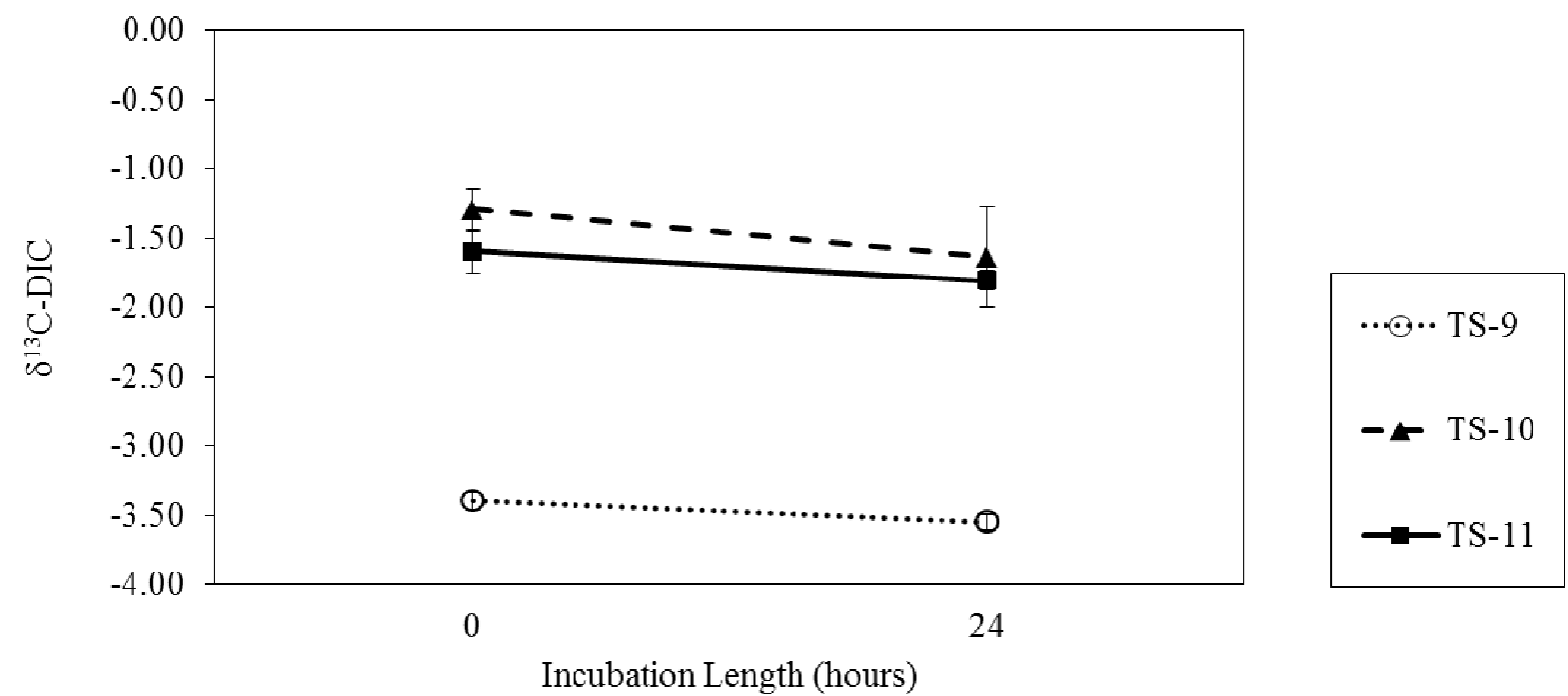

Figure 18: Changes in $\delta^{13} \mathrm{C}$-DIC in incubated unlabeled samples collected from TS-9, TS-10, and TS-11 on July $24^{\text {th }}, 2013$.

$\delta^{13} \mathrm{C}$-DIC values were converted into $\mu \mathrm{g} \mathrm{C} \mathrm{\textrm {L } ^ { - 1 }}$ using a linear regression between DIC standards and peak amplitudes measured by the GC-IRMS (Figure 19), as well as additional calculations previously described in the methods section. Conversion of $\delta^{13} \mathrm{C}$ DIC to $\mu \mathrm{g} \mathrm{C} \mathrm{L} \mathrm{L}^{-1}$ generally weakened correlations with incubation time. This resulted from highly variable peak amplitudes playing a larger role than $\delta^{13} \mathrm{C}$ values in calculations. Significant differences between incubation times were not found for unlabeled samples from May $23^{\text {rd }}$ and June $26^{\text {th }}(p=0.35,0.20)$ or for labeled samples from June $11^{\text {th }}(\mathrm{p}=0.45)$. A significant difference among incubation times was found for labeled May $23^{\text {rd }}$ samples $(p=0.02)$. However, an apparent decrease in $\mu \mathrm{g} \mathrm{C} \mathrm{L}^{-1}$ occurred rather than an increase over time (Figure 20). Similar results were found for unlabeled June $11^{\text {th }}$ samples. Although differences were found between 24 hour and 48 hour samples $\left(\mathrm{p}=0.02, \mathrm{q}>\mathrm{q}_{\text {critical }}\right)$, calculated $\mathrm{C}$ concentrations decreased from an 
average of 532 to an average of $393 \mu \mathrm{g} \mathrm{C} \mathrm{L}^{-1}$ during those hours. A significant difference was also found between initial and 48 hour samples for June $26^{\text {th }}$ samples $(\mathrm{p}=$ $\left.0.03, \mathrm{q}>\mathrm{q}_{\text {critical }}\right)$. Although this significant difference was found, the relationship between $\mu \mathrm{g} \mathrm{C} \mathrm{L^{-1 }}$ and incubation time on June $26^{\text {th }}(r=0.82$, Figure 21$)$ was much weaker than the relationship previously shown between unconverted $\delta^{13} \mathrm{C}$ and incubation time $(r=0.99)$. 

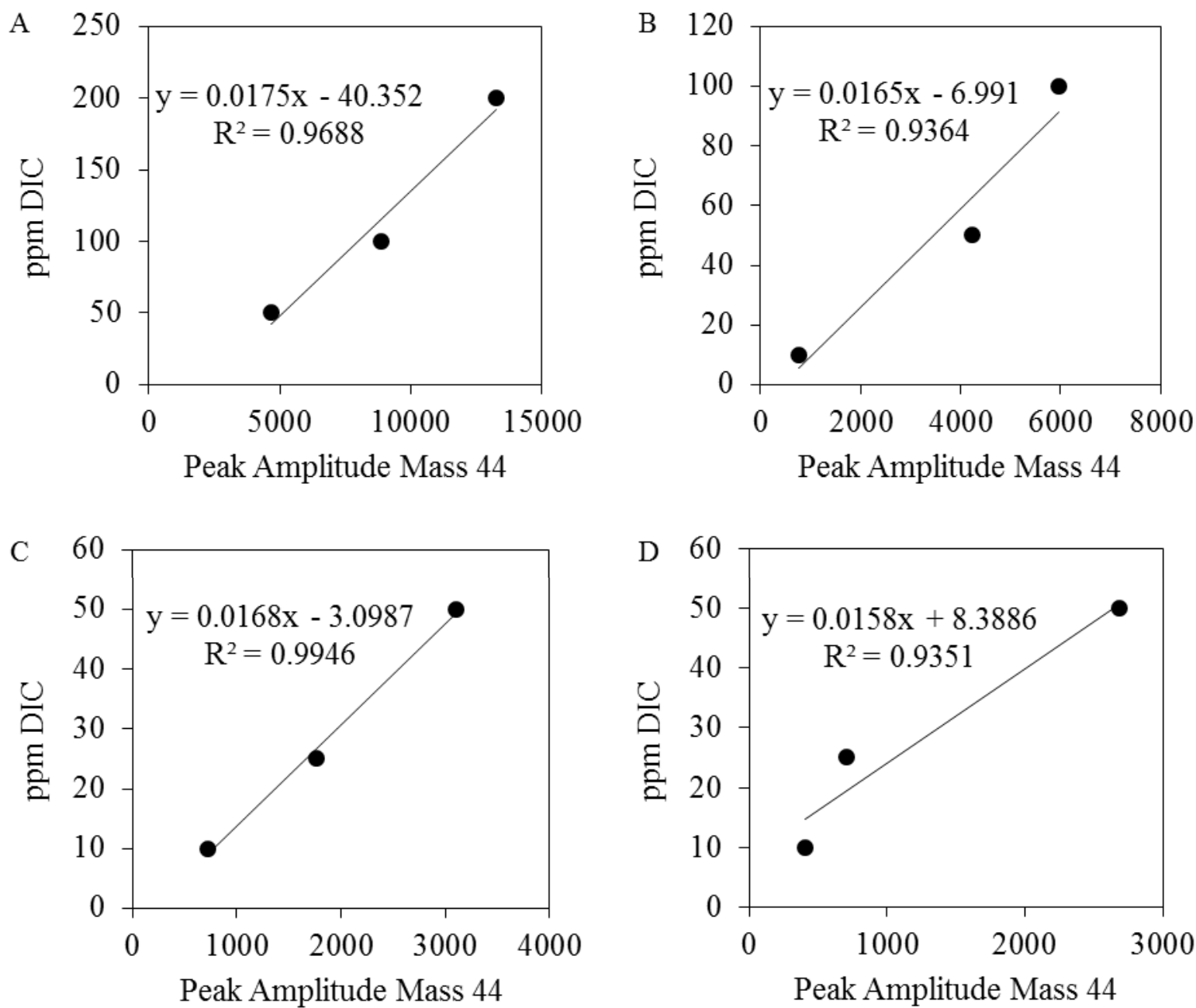

Figure 19: Linear regression between mass 44 peak amplitude measured via GC-IRMS and DIC measured in parts per million for each sampling event. Graph A was generated for May $23^{\text {rd }}$ data, graph B for June $11^{\text {th }}$ data, graph C for June $26^{\text {th }}$ data and graph D for July $24^{\text {th }}$ data.

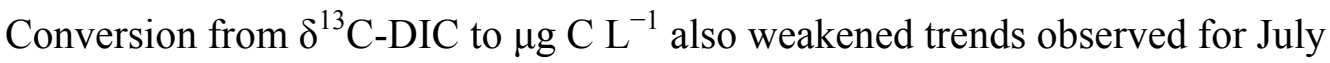
$24^{\text {th }}$ samples (Figure 22, Figure 23). Although significant changes in $\delta^{13} \mathrm{C}$-DIC were found for labeled TS-9 and TS-11 samples, no significant change was observed during incubation for all three sites when data were converted to $\mu \mathrm{g} \mathrm{C} \mathrm{L}^{-1}(\mathrm{p}=0.15,0.09$ and 
0.18 for TS-9, TS-10 and TS-11, respectively). Significant changes were also not observed for unlabeled samples collected on July $24^{\text {th }}$ after data conversion to $\mu \mathrm{g} \mathrm{C} \mathrm{L^{-1 }}$ (p $=0.12,0.16$ and 0.11 for TS-9, TS-10 and TS-11, respectively).

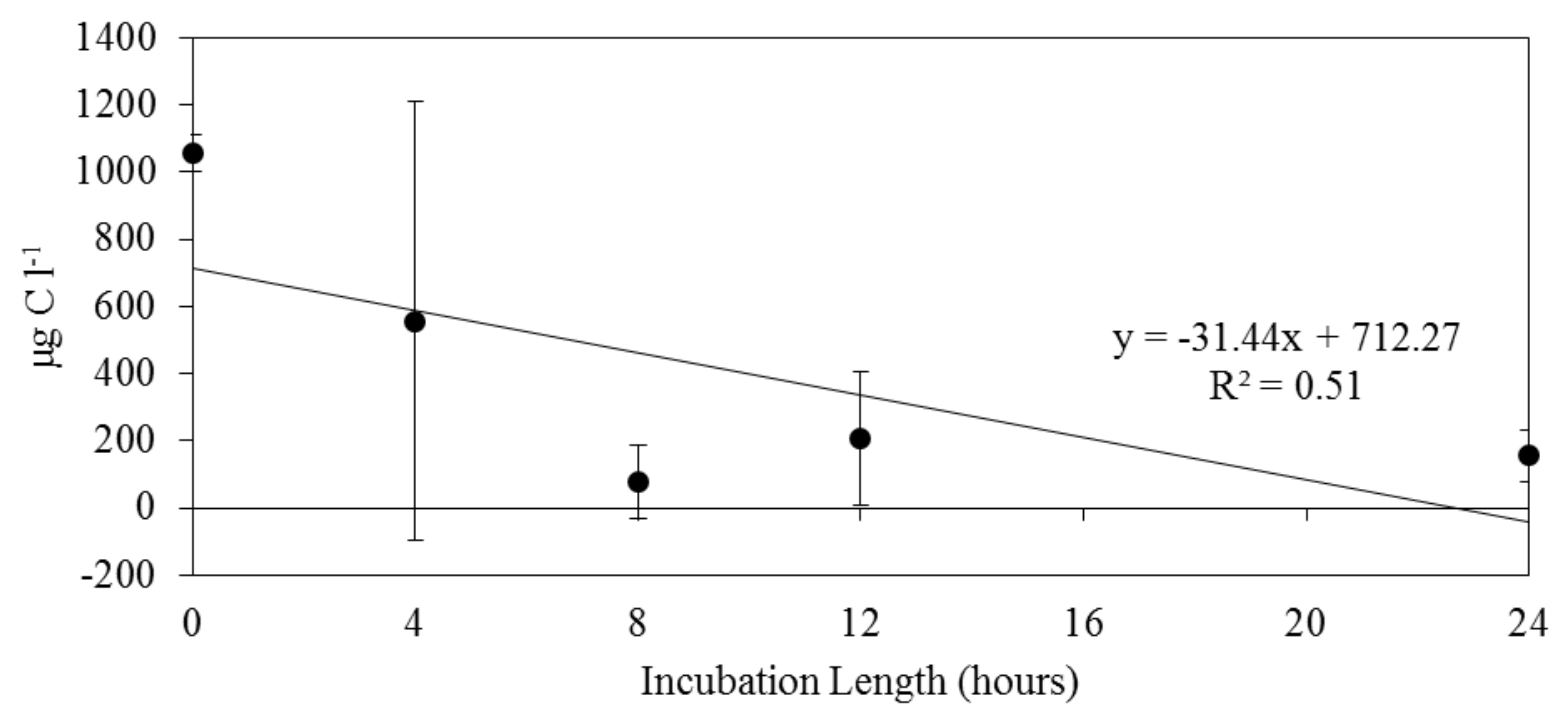

Figure 20: Relationship between $\delta^{13} \mathrm{C}$-DIC values converted into $\mu \mathrm{g} \mathrm{C} \mathrm{L}^{-1}$ and incubation time for samples collected on May $23^{\text {rd }}, 2013$.

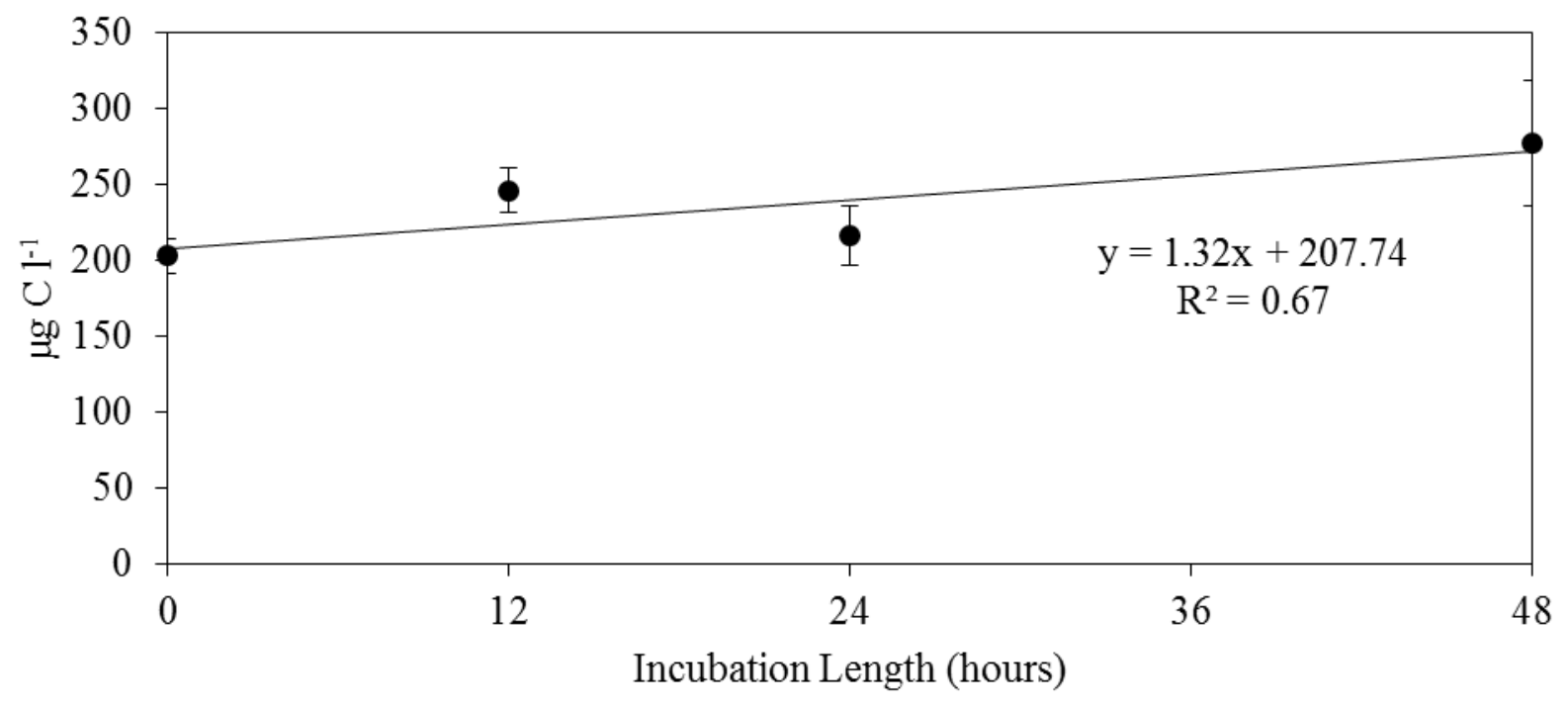

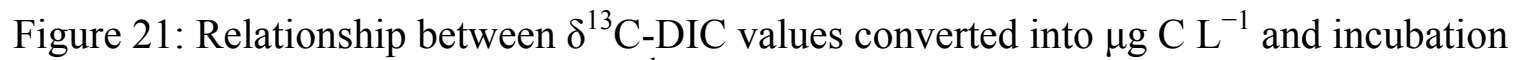
time for samples collected on June $26^{\text {th }}, 2013$. 

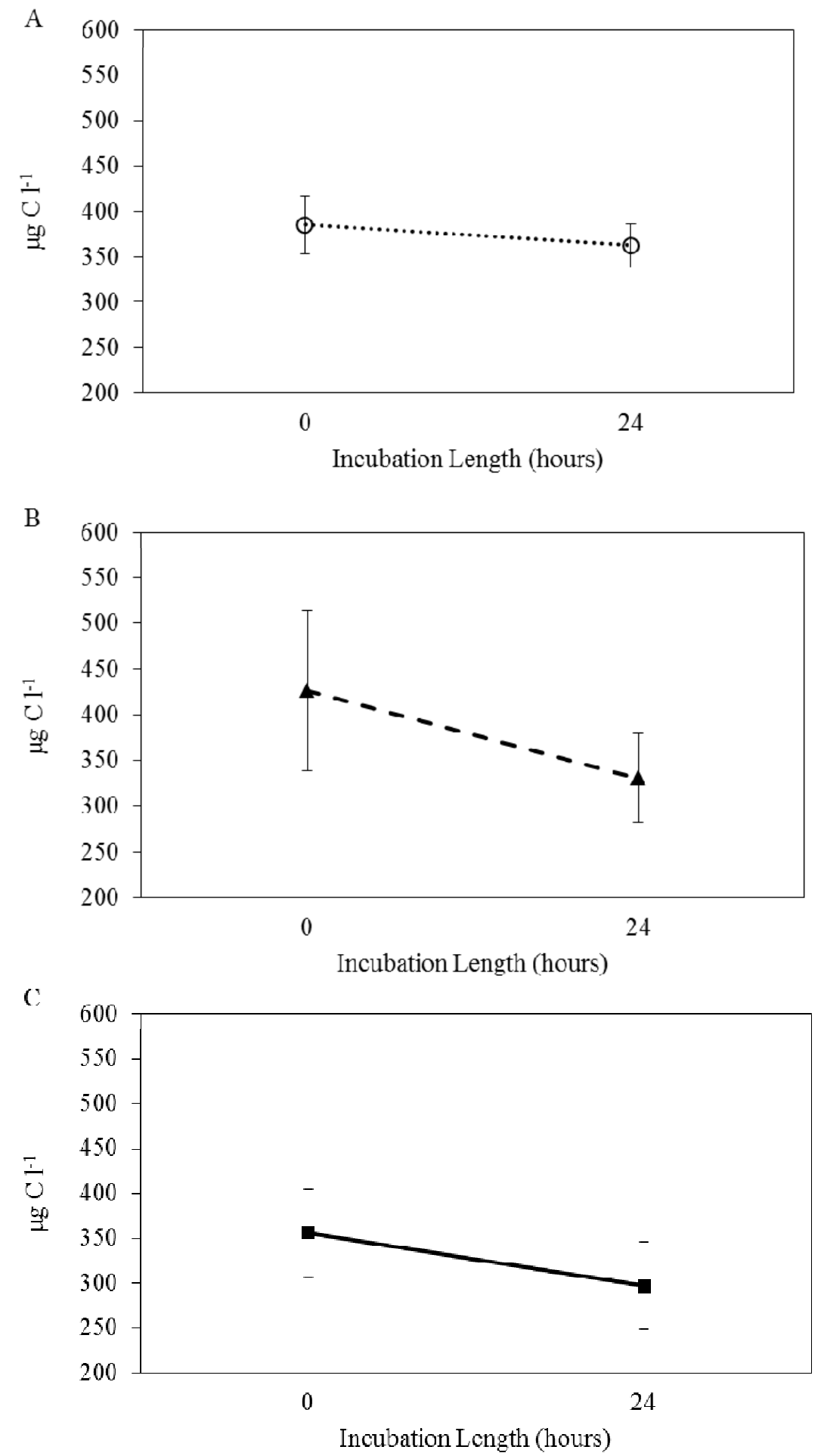

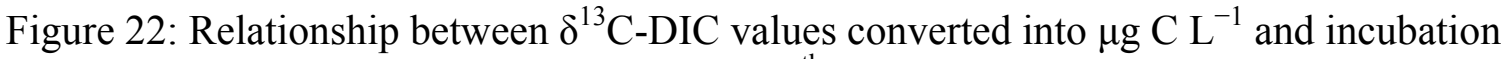
time for unlabeled samples collected on July $24^{\text {th }}, 2013$. Graph A represents TS-9 data, graph B represents TS-10 data, and graph C represents TS-11 data. 

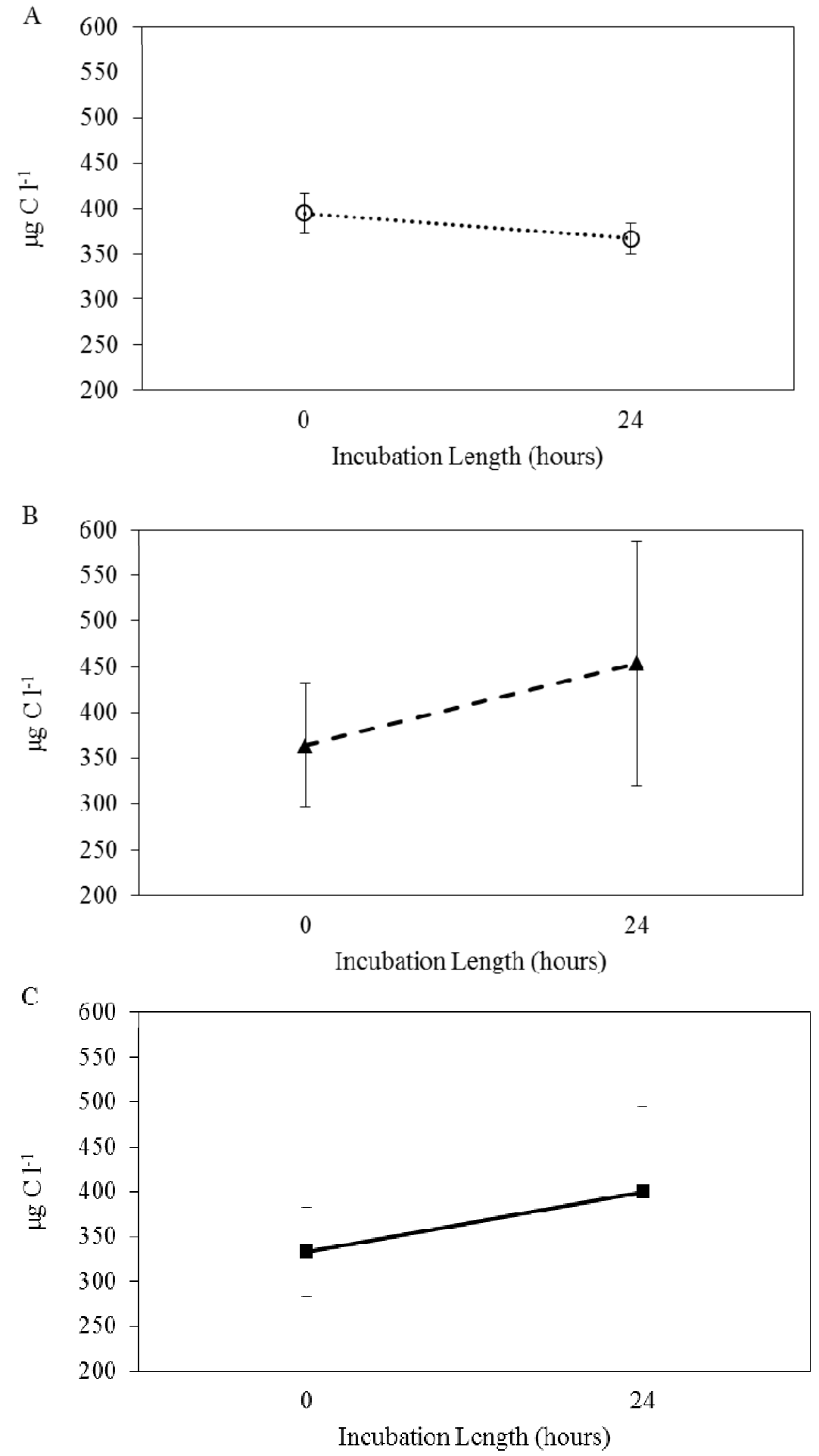

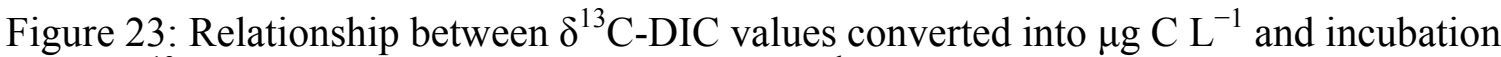
time for ${ }^{13} \mathrm{C}$-labeled samples collected on July $24^{\text {th }}, 2013$. Graph A represents TS-9 data, graph B represents TS-10 data, and graph C represents TS-11 data. 
Respiration rates calculated from both Winkler titrations and $\delta^{13} \mathrm{C}$-DIC were used to create estimates of baseline bacterial growth efficiency for each sampling site and location (Table 3). As reviewed previously, a large portion of the BR results were negative because of calculated decreases in DIC rather than increases expected during the respiration process (these are represented as $<0.001$ in Table 3). Additionally, conversion of raw respiration data to $\mu \mathrm{g} \mathrm{C} \mathrm{L} \mathrm{L}^{-1}$ resulted in labeled TS-9 results from June being the only statistically significant positive result. Although data conversion weakened statistical significance of the results, general trends can still be noted in relation to the raw data. For example, raw labeled ${ }^{13}$ C-DIC results for TS-9 and TS-11 in July were statistically significant. Respiration calculated from the labeled ${ }^{13} \mathrm{C}$ method as well as BP were higher at TS-11 than TS-9. When BGE is calculated from these results, TS-11 shows a higher BGE $(0.108)$ than TS-9 $(<0.001)$. The same relationship is observed in BGE calculations from the traditional Winkler titration method (BGE TS-9 $=0.039$, BGE TS-11 $=0.258)$.

Table 3: Bacterial production, bacterial respiration (in $\mathrm{ug} \mathrm{C} \mathrm{L}^{-1} \mathrm{hr}^{-1}$ ) and bacterial growth efficiency calculations for all sampling events. Asterisks represent statistically signficant

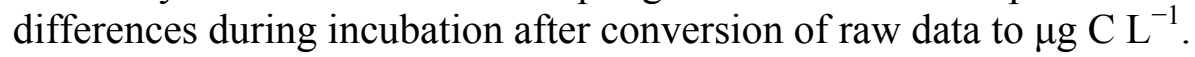

\begin{tabular}{cccccccc}
\hline $\begin{array}{c}\text { Sampling } \\
\text { Location }\end{array}$ & BP & $\begin{array}{c}\text { BR } \\
\text { Unlabeled } \\
{ }^{13} \mathrm{C}\end{array}$ & $\begin{array}{c}\text { BR } \\
\text { Labeled } \\
{ }^{13} \mathrm{C}\end{array}$ & $\begin{array}{c}\mathrm{BR} \\
\text { Winkler }\end{array}$ & $\begin{array}{c}\mathrm{BGE} \\
\text { Unlabeled } \\
{ }^{13} \mathrm{C}\end{array}$ & $\begin{array}{c}\mathrm{BGE} \\
\text { Labeled } \\
{ }^{13} \mathrm{C}\end{array}$ & $\begin{array}{c}\mathrm{BGE} \\
\text { Winkler }\end{array}$ \\
\hline $\begin{array}{c}\text { Biscayne } \\
\text { Bay 1 }\end{array}$ & $<0.001$ & 2.440 & $<0.001^{*}$ & 2.960 & $<0.001$ & 0.001 & $<0.001$ \\
$\begin{array}{c}\text { Biscayne } \\
\text { Bay 2 }\end{array}$ & 1.884 & 0.090 & $<0.001^{*}$ & $<0.001$ & 0.954 & $\geq 1.000$ & $\geq 1.000$ \\
TS-9 (June) & 0.012 & $<0.001$ & $1.325^{*}$ & $<0.001^{*}$ & $<0.001$ & 0.009 & $<0.001$ \\
TS-9 (July) & 0.118 & $<0.001$ & $<0.001^{*}$ & 2.890 & $<0.001$ & $<0.001$ & 0.039 \\
TS-10 (July) & 0.029 & $<0.001$ & 3.738 & 2.990 & $<0.001$ & 0.008 & 0.010 \\
TS-11 (July) & 0.340 & $<0.001$ & 2.795 & 0.980 & $<0.001$ & 0.108 & 0.258 \\
\hline
\end{tabular}




\section{DISCUSSION}

Previous characterization of BA, BP, BR and BGE in Florida Bay is highly limited. Bacterial abundance and BP have been examined by Boyer et al. (2006) at TS-9 and TS-10. Data from that study were gathered monthly between July 2001 and July 2002. Median BA values reported in the Boyer et al. (2006) study at TS-9 and TS-10 were $2 \times 10^{6}$ cells ml $^{-1}$ and $3 \times 10^{6}$ cells ml $^{-1}$, respectively. Bacterial abundance values in Florida Bay produced from the current study range from 4.7 to $5.7 \times 10^{6}$ cells $^{-1}$. Though these results are higher than median values reported by Boyer et al. (2006), these values are still within range of the range of BA reported in the previous study. July 2013 BA results were similar across all three Florida Bay sites $\left(4.7\right.$ to $4.9 \times 10^{6}$ cells ml $\left.^{-1}\right)$ and

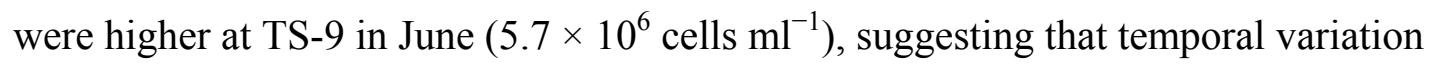
rather than spatial variation was an influence on BA in the current study.

Bacterial production was also examined in the Boyer et al. (2006) study at TS-9 and TS-10. The BP median was approximately $1 \mu \mathrm{g} \mathrm{C} \mathrm{L} \mathrm{day}{ }^{-1}$ at TS-9, while the median at TS-10 was approximately $0.75 \mu \mathrm{g} \mathrm{C} \mathrm{L}^{-1}$. Average BP values in the current study were $0.29 \mu \mathrm{g} \mathrm{C} \mathrm{L} \mathrm{day}{ }^{-1}$ in June at TS-9, $2.84 \mu \mathrm{g} \mathrm{C} \mathrm{L} \mathrm{day}{ }^{-1}$ in July at TS-9, 0.70 in July at TS-10, and $8.16 \mu \mathrm{g} \mathrm{C} \mathrm{L} \mathrm{day}{ }^{-1}$ in July at TS-11. Results from July in the current study show TS-9 having a higher BP rate than TS-10, similar to results in the Boyer et al. (2006) study. June TS-9 results, however, were lower than those found at TS-10. These BP results suggest that seasonal variation, such as incoming Everglades runoff at TS-9 during the wet season, may impact microbial parameters. Additionally, comparatively higher BP results at TS-11 suggest that BP may also be influenced by nutrient limitation gradients. 
The challenge of measuring BR in oligotrophic environments has limited BR research in Florida Bay. Budgen et al. (1998) examined heterotrophic activity through bacterial ${ }^{14} \mathrm{CO}_{2}$ uptake and respiration. Bugden et al. (1998) found that heterotrophic activity was generally higher in western Florida Bay $\left(0.5 \mu \mathrm{g} \mathrm{Ch}{ }^{-1}\right)$ than in eastern Florida Bay $\left(0.25 \mu \mathrm{g} \mathrm{C} \mathrm{h}^{-1}\right)$. The Bugden et al. (1998) study linked differences in heterotrophic activity among sample sites to seagrass health rather than nutrient limitation status. Clear BR differences among sites were not apparent in the current study as a result of methodological challenges. Bacterial respiration calculations using all three methods ranged from negative to $2.89 \mu \mathrm{g} \mathrm{Ch} \mathrm{h}^{-1}$ at TS-9, negative to $3.74 \mu \mathrm{g} \mathrm{Ch}{ }^{-1}$ at TS-10, and negative to $2.80 \mu \mathrm{g} \mathrm{C} \mathrm{h}{ }^{-1}$ at TS-11. Raw $\delta^{13} \mathrm{C}$-DIC data, however, suggest that respiration may be highest at TS-11. TS- 11 showed the greatest change in $\delta^{13} \mathrm{C}$ in ${ }^{13} \mathrm{C}$-labeled samples $(-1.56 \%$ to $+6.28 \%$ ) in comparison to TS-9 and TS-10 in July. Although Winkler titration data suggests that TS-11 had the lowest BR among the Florida Bay sites, the Winkler titration results from all three sites were found to be nonsignificant.

The ${ }^{13} \mathrm{C}$-labeling method of measuring BR may be a viable alternative to Winkler titrations on the basis of strong correlations between $\delta^{13} \mathrm{C}$-DIC and incubation time.

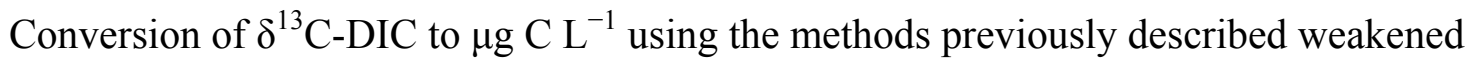
correlations. In future studies employing $\delta^{13} \mathrm{C}$-DIC as a way to measure BR, a more complete tracing of carbon pathways could result in better correlations. For example, both DIC and DOC concentrations could be measured, in addition to $\delta^{13} \mathrm{C}$-DIC and $\delta^{13} \mathrm{C}$ DOC measurements using GC-IRMS. Additionally, more work will be needed for applying the method to eutrophic systems. BR results from June $11^{\text {th }}$ suggest that a shorter incubation length is needed in mesotrophic and eutrophic systems in order to 
observe a linear uptake of ${ }^{13} \mathrm{C}$-glucose. Although a significant change in $\delta^{13} \mathrm{C}$-DIC was observed between 0 and 24 hours of incubation during the June $11^{\text {th }}$ sampling event, respiration of consumed ${ }^{13} \mathrm{C}$-glucose may have plateaued before 24 hours of incubation. Thus, inclusion of shorter incubation times in these environments may produce better data to describe BR.

Typical values for BGE in the literature range from 0.01 to 0.50 , with a maximum literature value of 5 (del Giorgio and Cole 1998). When excluding negative BGE calculations, most the results from this study fall into the low range when compared to literature values. The resulting BGE calculations matched overall expectations of low BGE being present in historically low nutrient environments.

Evidence of terrestrial runoff impacting microbial results is present in the current data set and is supported by previous studies. Previous work has shown that freshwater runoff into estuaries lowers both salinity and $\delta^{13}$ C-DIC values (Mook and Tan 1991, Fry 2002, Atekwana et al. 2003). Additionally, previous studies have also indicated that terrestrial runoff can impact bacterial parameters. Cotner et al. (2000) found that site proximity in Florida Bay to Everglades runoff can influence BP and also found that BP is up to an order of magnitude higher during the wet season than during the dry season. Lavrentyev et al. (1998) found that nutrient input and freshwater inflow in Florida Bay impacted microbial community structure, resulting in three distinct microbial community structures dependent upon location within Florida Bay. In the current data set, impacts of terrestrial runoff may be present in June Biscayne Bay samples and July TS-9 samples. June Biscayne Bay samples had lower salinity (17 psu) and lower initial $\delta^{13} \mathrm{C}-\mathrm{DIC}$ values $(-8.28 \%$ to $-8.10 \%)$ than all other samples collected. The June Biscayne Bay samples 
also had the highest BP and BA values. Although May Biscayne Bay samples had BP and BR results more similar to oligotrophic Florida Bay samples, differences between May and June samples can be attributed to minor differences in sampling location (center of navigation channel in May vs. shoreline location in June) and rainfall influence (recent tropical storm for June samples). Similar comparisons can be made between June TS-9 and July TS-9 samples. June TS-9 samples had a higher salinity (33.4 psu) and higher initial $\delta^{13} \mathrm{C}-\mathrm{DIC}$ values $(-2.45 \%$ to $-2.48 \%$ ) than July TS-9 samples (21.1 psu, $-3.52 \%$ o to $-3.33 \%$ ), indicating July TS-9 samples may have been influenced by freshwater input. July TS-9 samples also had higher BP rates, though BA was higher in June at TS-9 than in July. Stronger similarities were present between June TS-9 and July TS-10 results, particularly in regard to salinity (33.4 vs. 34.7) and BP rates (0.012 vs. $0.029 \mu \mathrm{g} \mathrm{C} \mathrm{L}^{-1}$ $\mathrm{h}^{-1}$ ). These comparisons suggest that freshwater influence at TS-9 increased in July after the start of the wet season. Although the Florida Bay sampling events were separated by only one month, potential seasonal influences are present in the data.

\section{CONCLUSION}

The results of this study indicated that tracing of ${ }^{13} \mathrm{C}$ may serve as a better method of measuring BR in oligotrophic systems than traditional Winkler titration-based DO consumption measurements. The original hypothesis that the Winkler titration method could be used in a mesotrophic environment to calibrate the ${ }^{13} \mathrm{C}$-based methods was incorrect. In both Florida Bay and Biscayne Bay, changes in DO before and after dark incubation were found to be either insignificant or highly variable, making the Winkler titration an invalid method of determining BR in these environments. Bacterial 
abundance and BP results indicated that Biscayne Bay was a higher productivity site than the Florida Bay sites; however, BR was still not measureable by Winkler titration. In future studies, the labeled and natural ${ }^{13} \mathrm{C}$ BR methods can be compared to BR measured by Winkler titration in a more eutrophic environment.

In comparison to the tracing of natural ${ }^{13} \mathrm{C}$ ratios, the ${ }^{13} \mathrm{C}$-glucose consumption method, also referred to as the ${ }^{13} \mathrm{C}$ labeling method, produced better $\mathrm{BR}$ results. Changes in natural $\delta^{13} \mathrm{C}$-DIC ratios before and after dark incubation were largely insignificant throughout the study. Samples spiked with ${ }^{13} \mathrm{C}$-glucose, however, produced strong correlations between $\delta^{13} \mathrm{C}$-DIC and incubation time during 3 of the 4 sampling events. While the tracing of natural ${ }^{13} \mathrm{C}$ ratios would have been more ideal for determining realistic BR values on the basis of bacterial consumption of natural DOC sources, the correlations produced by this method were too weak to be used reliably for BR measurements.

The correlations produced by the labeled ${ }^{13} \mathrm{C}$ method suggest that this method could be used to measure BR and BGE in oligotrophic systems. When $\delta^{13} \mathrm{C}$-DIC values were converted into $\mu \mathrm{g} \mathrm{C}$ respired, correlations were greatly weakened. Peak amplitudes measured by GC-IRMS were used to produce DIC concentrations during this conversion. While concentrations of DIC can be produced from GC-IRMS data, future studies could use more specialized instrumentation specifically designed for DIC and DOC measurements, such as a total organic carbon analyzer. In order to address potential concerns about isotopic dilution, future experiments can also examine ${ }^{13} \mathrm{C}$-glucose additions at varying concentrations, similar to methods used in radiotracer studies (Simon 
and Azam 1989). These additional measurements may refine bacterial energy pathways and improve conversion of $\delta^{13} \mathrm{C}$-DIC into respiration values.

This study was designed to measure BR, BGE and other carbon pathways specifically within the Florida Bay ecosystem. Beyond determination of Florida Bay carbon cycling components, the ${ }^{13} \mathrm{C}$ tracing method may be a way to determine $\mathrm{BR}$ and BGE in other environments where these measurements are difficult to make, such as lowproductivity pelagic marine environments. Currently, techniques are being developed to measure $\delta^{13} \mathrm{C}$-DIC using lower cost and more portable cavity ring-down mass spectroscopy (CRDS) systems (Hartland et al. 2012). While GC-IRMS would be impractical to utilize in field studies, CRDS has the potential to be used outside of traditional laboratories. The GC-IRMS method described in this study can ultimately be adapted to CRDS systems, allowing a field-based alternative to traditional techniques of quantifying microbial respiration in open oceanic waters.

The BR methodologies described in this study will need further refinement before reliable BGE values can be calculated from Florida Bay. Overall, data gathered in this study suggest that BGE is lower in highly nutrient limited Eastern Florida Bay than in Western Florida Bay. Further application of the methods described in this study can be used to explore other factors in Florida Bay that could affect BGE. Differences between June and July results suggest that seasonal variation, particularly in relation to water input from the Everglades, could impact BR, BP and BGE in Florida Bay. Additional longterm studies could explore the influence of this potential variable on BGE. Further laboratory and mesocosm studies could isolate other variables that may impact Florida Bay BGE, such as salinity and nutrient concentrations. With the addition of these 
suggested long-term BGE studies, the role of Florida Bay water column microbes can be better understood in relation to carbon cycles in Florida Bay and the southern Everglades. Because the southern Everglades and Florida Bay may serve as an important carbon sink, further assessment of BGE throughout this system is warranted. 


\section{REFERENCES}

Apple, J.K., and P.A. del Giorgio. 2007. Organic substrate quality as the link between bacterioplankton carbon demand and growth efficiency in a temperate salt-marsh estuary. ISME Journal 1(8): 1-14.

Aranguren-Gassis, M., E. Teira, P. Serret, S. Martinez-Garcia, and E. Fernandez. 2012. Potential overestimation of bacterial respiration rates in oligotrophic plankton communities. Mar. Ecol. Prog. Ser. 453: 1-10.

Arrigo, K. 2005. Marine microorganisms and global nutrient cycles. Nature 437: 349355.

Atekwana, E.A., L.P. Tedesco, and L.R. Jackson. 2003. Dissolved inorganic carbon (DIC) and hydrologic mixing in a subtropical marine estuary, Southwest Florida, USA. Estuaries 26(6): 1391-1400.

Azam, F., T. Fenchel, J.G. Field, J.S. Gray, L.A. Meyer-Reil, and F. Thingstad. 1983. The ecological role of water-column microbes in the sea. Mar. Ecol. Prog. Ser. 10: 257-263.

Bell, R.T. 1993. Estimating production of heterotrophic bacterio-plankton via incorporation of tritiated thymidine, pp. 495-503. In P.F. Kemp, B.F. Sherr, E.B. Sherr and J.J. Cole (Eds.), Handbook of Methods in Aquatic Microbial Ecology. Lewis Publishers.

Biddanda, B., S. Opsahl, and R. Benner. 1994. Plankton respiration and carbon flux through bacterioplankton. Limnol. Oceanogr. 39: 1259-1275.

Bjørnsen, P.K. 1986. Bacterioplankton growth yield in continuous seawater cultures. Mar. Ecol. Prog. Ser. 30: 191-196.

Bouillon, S. 2011. Carbon cycle: Storage beneath mangroves. Nat. Geosci. 4: 282-283.

Boyer, J.N., J.W. Fourqurean and R.D. Jones. 1997. Spatial characterization of water of water quality in Florida Bay and Whitewater Bay by multivariate analyses: Zones of similar influence. Estuaries 20: 743-758.

Boyer, J.N., and R.D. Jones. 2001. Long-term trends in water quality of Florida Bay (June 1989-June 1999) pp 64-66. In 2001 Florida Bay Science Conference. (Abstract).

Boyer, J.N., S.K. Dailey, P.J. Gibson, M.T. Rodgers, and D. Mir-Gonzalez. 2006. The role of dissolved organic matter bioavailability in promoting phytoplankton blooms in Florida Bay. Hydrobiologia 569: 71-85. 
Bugden, J.B., M.A. Guerrero, and R.D. Jones. 1998. Spatial and temporal variation of marine bacterioplankton in Florida Bay, USA. J. Coastal Res. 14(4): 1304-1313.

Carpenter, J.H. 1965. The Chesapeake Bay Institute technique for the Winkler dissolved oxygen method. Limnol. Oceanogr. 10(1): 141-143.

Caccia, V.G., and J.N. Boyer. 2005. Spatial patterning of water quality in Biscayne Bay, Florida as a function of land use and water management. Mar. Pollut. Bull. 50: 1416-1429.

Caccia, V.G. and J.N. Boyer. 2007. A nutrient loading budget for Biscayne Bay, Florida. Mar. Pollut. Bull. 54: 994-1008.

Childers, D., J. Boyer, S. Davis, C. Madden, D. Rudnick, and F. Sklar. 2006. Relating precipitation and water management to nutrient concentrations in the oligotrophic "upside-down" estuaries of the Florida Everglades. Limnol. Oceanogr. 51(1): 602-616.

Chin-Leo, G., and R. Benner. 1992. Enhanced bacterioplankton production and respiration at intermediate salinities in the Mississippi River plume. Mar. Ecol. Prog. Ser. 87: 87-103.

Coleman, A. 1980. Enhanced detection of bacteria in natural environments by fluorochrome staining of DNA. Limnol. Oceanogr. 25(5): 948-951.

Cotner, J.B., R.H. Sada, H.A. Bottsma, T.H. Johengen, and W.S. Gardner. 2000. Nutrient limitation of heterotrophic bacteria in Florida Bay. Estuaries 23(5): 611620 .

Craig, H. 1957. Isotopic standards for carbon and oxygen and correction factors for mass-spectrometric analysis of carbon dioxide. Geochim. Cosmochim. Acta 12(1): 133-149.

del Giorgio, P.A., J.J. Cole, and A. Cimberlis. 1997. Respiration rates in bacteria exceed phytoplankton production in unproductive systems. Nature 385: 148-151.

del Giorgio, P.A., and J.J. Cole. 1998. Bacterial growth efficiency in natural aquatic systems. Annu. Rev. Ecol. Sys. 29: 503-541.

Doctor, D.H., C. Kendall, S.D. Sebestyen, J.B. Shanley, N. Ohte, and E.W. Boyer. 2008. Carbon isotope fractionation of dissolved inorganic carbon (DIC) due to outgassing of carbon dioxide from a headwater stream. Hydrol. Process. 22(14): 2410-2423. 
Donato, D.C., J.B. Kauffman, D. Murdiyarso, S. Kurnianto, M. Stidham, and M. Kanninen. 2011. Mangroves among the most carbon-rich forests in the tropics. Nat. Geosci. 4 (5): 293-297.

DuFore, C. 2012. Spatial and Temporal Variations in the Air-Sea Carbon Dioxide Fluxes of Florida Bay. Master's Thesis, University of South Florida.

Eiler, A. S. Langenheder, S. Bertilsson, and L. Tranvik. 2003. Heterotrophic bacterial growth efficiency and community structure at different natural organic carbon concentrations. Appl. Environ. Microbiol. 69(7): 3701-3709.

Engel, V., J.G. Barr, J.D. Fuentes, V.H. Rivera-Monroy, E. Castaneda-Moya, T. Troxler, D. Ho, S. Ferron-Smith, J.M. Smoak, T.J. Smith, and R.R. Twilley. 2011. Net ecosystem carbon balance in a tidal mangrove forest. Presentation at the AmeriFlux Science Meeting \& 3rd NACP All-Investigators Meeting. New Orleans, Louisiana, February 03, 2011.

Friederich, G.E., L.A. Codispoti, and C.M. Sakamoto. 1991. An easy-to-construct automated Winkler titration system. Monterey Bay Aquarium Research Institute Technical Report No. 91-6.

Fry, B. 2002. Conservative mixing of stable isotopes across estuarine salinity gradients: a conceptual framework for monitoring watershed influences on downstream fisheries production. Estuaries 25(2): 264-271.

Fry, B. 2006. Stable Isotope Ecology. Springer.

Fuhrman, J.A., and F. Azam. 1982. Thymidine incorporation as a measure of heterotrophic bacterioplankton production in marine surface waters: evaluation and field results. Mar. Biol. 66: 109-120.

Fourqurean, J.W., C.M. Duarte., H. Kennedy, N. Marbà, N. Holmer, M.A. Mateo, E.T. Apostolaki, G.A. Kendrick, D. Krause-Jensen, K.J. McGlathery, and O. Serrano. 2012. Seagrass ecosystems as a globally significant carbon stock. Nature Geosci. 5: 505-509.

Fourqurean, J., G. Kendrick, L. Collins, R. Chambers, and M. Vanderklift. 2012. Carbon, nitrogen and phosphorus storage in subtropical seagrass meadows: Examples from Florida Bay and Shark Bay. Mar. Freshwater Res. 63(11): 967983.

Fourqurean, J., and M. Robblee. 1999. Florida Bay: a history of recent ecological changes. Estuaries 22(28): 345-357. 
Griffiths, R.P., B.A. Caldwell, and R.Y. Morita. 1984. Observations on microbial percent respiration values in arctic and subarctic marine waters and sediments. Microb. Ecol. 10: 151-164.

Hartland, A., A. Baker, W. Timms, Y. Shutova, and D. Yu. 2012. Measuring dissolved organic carbon $\delta^{13} \mathrm{C}$ in freshwaters using total organic carbon cavity ring-down spectroscopy. Environ. Chem Lett. 10(3): 309-315.

Hobbie, J.E. and C.C. Crawford. 1969. Respiration corrections for bacterial uptake of dissolved organic compounds in natural waters. Limnol. Oceanogr. 14: 528-532.

Hoffmeister, J. 1974. Land from the Sea: The Geologic Story of South Florida. University of Miami Press.

King, G.M., and T. Berman. 1984. Potential effects of isotopic dilution on apparent respiration in ${ }^{14} \mathrm{C}$ heterotrophy experiments. Mar. Ecol. Prog. Ser. 19: 175-80.

Kirchman, D.L., E. K’Nees, and R.E. Hodson. 1985. Leucine incorporation and its potential as a measure of protein synthesis by bacteria in natural aquatic systems. Appl. Environ. Microbiol. 49: 599-607.

Kirchman, D. L. 2003. The contribution of monomers and other low-molecular weight compounds to the flux of dissolved organic material in aquatic ecosystems $\mathrm{pp}$ 218-237. In S.E. Findlay, and R.L. Sinsabaugh (Eds.), Aquatic Ecosystems: Interactivity of Dissolved Organic Matter. Academic Press.

Lavrentyev, P.J. H.A. Bootsma, T.J. Johengen, J.F. Cavaletto, and W.S. Gardner. 1998. Microbial plankton response to resource limitation: insights from the community structure and seston stoichiometry in Florida Bay, USA. Mar. Ecol. Prog. Ser. 165: 45-57.

Lennon, J.T., and L.E. Pfaff. 2005. Source and supply of terrestrial organic matter affects aquatic microbial metabolism. Aquat. Microb. Ecol. 39: 107-119.

Li, X. and W. Liu. 2011. Effect of preservation on the $\delta^{13} \mathrm{C}$ value of dissolved inorganic carbon in different types of water samples. Isot. Environ. Healt. S. 47: 379-389.

Mcleod, E., G.L. Chmura, S. Bouillon, R. Salm, M. Björk, C.M. Duarte, C.E. Lovelock, W.H. Schlesinger, and B.R. Silliman. 2011. A blueprint for blue carbon: toward an improved understanding of vegetated coastal habitats in sequestering $\mathrm{CO}_{2}$. Front. Ecol. Environ. 9: 552-560.

Mook, W.G. and F.C. Tan. 1991. Stable carbon isotopes in rivers and estuaries pp 245264. In E.T. Degens, S. Kempe, and J.E. Richey (Eds.), Biogeochemistry of Major World Rivers, SCOPE 42. John Wiley \& Sons, Inc. 
Obeysekera, J., J. Browder, L. Hornung, and M. Harwell. 1999. The natural South Florida system I: Climate, geology, and hydrology. Urban Ecosyst. 3: 223-244.

Parsons, T.R. and J.D.H. Strickland. 1961. On the production of particulate organic carbon by heterotrophic processes in sea water. Deep Sea Res. 8(3): 211-222.

Phlips, E.J., S. Badylak, and T.C. Lynch. 1999. Blooms of the picoplanktonic cyanobacterium Synechococcus in Florida Bay, a subtropical inner-shelf lagoon. Limnol. Oceanogr. 44: 1166-1175.

Porter, K. and Y. Feig. 1980. The use of DAPI for identifying and counting aquatic microflora. Limnol. Oceanogr. 25(5): 943-948.

Robblee, M.B., G. Clement, D. Smith, and R. Halley. 2001. Salinity patterns in Florida Bay: A synthesis (1900-2000) pp 34-36. In 2001 Florida Bay Science Conference. (Abstract).

Robinson, C. 2008. Heterotrophic bacterial respiration pp 299-334. In D.L. Kirchman (Ed.), Microbial Ecology of the Oceans, $2^{\text {nd }}$ Edn. John Wiley \& Sons, Inc.

Simon, M., and F. Azam. 1989. Protein content and protein synthesis rates of planktonic marine bacteria. Mar. Ecol. Prog. Ser. 51: 201-213.

Smoak, J.M., J.L. Breithaupt, T.J. Smith III, and C.J. Sanders. 2013. Sediment accretion and organic carbon burial relative to sea-level rise and storm events in two mangrove forests in Everglades National Park. Catena 104: 58-66.

Swart, P. and R. Price. 2002. Origin of salinity variations in Florida Bay. Limnol. Oceanogr. 47(4): 1234-1241.

St. Jean, G. 2003. Automated quantitative and isotopic $\left({ }^{13} \mathrm{C}\right)$ analysis of dissolved inorganic carbon and dissolved organic carbon in continuous-flow using a total organic carbon analyser. Rapid Commun. Mass Sp. 17(5): 419-428.

Taipale, S.J. and E. Sonninen. 2009. The influence of preservation method and time on the $\delta^{13} \mathrm{C}$ value of dissolved inorganic carbon in water samples. Rapid Commun. Mass Sp. 23: 2507-2510.

Torres, M.E., A.C. Mix, and W.D. Rugh. 2005. Precise $\delta^{13} \mathrm{C}$ analysis of dissolved inorganic carbon in natural waters using automated headspace sampling and continuous-flow mass spectrometry. Limnol. Oceanogr. Meth. 3: 349-360.

Wanless, H. and M. Tagett. 1989. Origin, growth and evolution of carbonate mudbanks in Florida Bay. B. Mar. Sci. 44(1): 454-489. 